\title{
Reconstruction of ocean environment time series since the late nineteenth century using sclerosponge geochemistry in the northwestern subtropical Pacific
}

Ryuji Asami ${ }^{1 *}\left(\mathbb{D}\right.$, Taketo Matsumori ${ }^{2}$, Ryuichi Shinjo², Ryu Uemura ${ }^{3}$, Yuki Miyaoka $^{4}$, Masaru Mizuyama ${ }^{5}$, Yuji Ise ${ }^{6}$ and Takashi Sakamaki

\begin{abstract}
The geochemistry of calcifying marine organisms is an excellent proxy for reconstructing paleoceanographic history, but studies of hypercalcified demosponges (sclerosponges) are considerably fewer than those of corals, foraminifers, and bivalves. For this study, we first generated near-annual resolved stable carbon and oxygen isotope $\left(\delta^{13} \mathrm{C}\right.$ and $\left.\delta^{18} \mathrm{O}\right)$ and element/Ca ratios ( $\mathrm{Sr} / \mathrm{Ca}, \mathrm{Ba} / \mathrm{Ca}, \mathrm{Pb} / \mathrm{Ca}, \mathrm{U} / \mathrm{Ca}$ ) time series for 1880-2015 from sclerosponge samples (Acanthochaetetes wellsi) collected at Miyako Island and Okinawa Island in the Ryukyu Islands of southwestern Japan. The $\delta^{13} \mathrm{C}$ records exhibited a typical variation of anthropogenically derived Suess effects, demonstrating that the rates of decrease of $-0.0043 \%$ /year before 1960 and - 0.024\%/year after 1960 in the northwestern subtropical Pacific were respectively similar to and about 1.4 times higher than those of the Caribbean Sea in the tropical Atlantic. Spectral analysis of the $\delta^{18} \mathrm{O}$ time series revealed significant periodicity of approximately $2,3,6.5,7-10$, and 20-30 year/cycle, indicating that sea surface conditions in the southern Ryukyu Islands had been dominated by interannual and decadal variations in temperature and seawater $\delta^{18} \mathrm{O}$ since the late nineteenth century. The Sr/Ca and $\mathrm{U} / \mathrm{Ca}$ ratios for the species A. wellsi (high-Mg calcite) might not be a robust proxy for seawater temperatures, unlike Astrosclera willeyana and Ceratoporella nicholsoni sclerosponges (aragonite). An evident increasing Pb/Ca trend after 1950 found in the samples is probably attributable to $\mathrm{Pb}$ emissions from industrial activities and atmospheric aerosols in eastern Asian countries. The Ba/Ca variations differ greatly among sampling sites, which might be attributable to the respective local environments. This evidence demonstrates that more high-resolution age determinations and geochemical profilings enable delineation of secular variations in ocean environments on annual and interannual timescales. Results of our study suggest that if sclerosponges living in deeper ocean environments are collected, spatial and vertical oceanographic variations for the last several centuries will be reconstructed along with coral proxy records.
\end{abstract}

Keywords: Sclerosponge, Acanthochaetetes wellsi, Oxygen and carbon isotopic composition, Minor and trace elements, Isotope equilibrium, Paleoenvironmental proxy, Ryukyu Islands

\footnotetext{
* Correspondence: ryuji.asami.b5@tohoku.ac.jp

'Institute of Geology and Paleontology, Graduate School of Science, Tohoku

University, 6-3, Aramaki-Aza-Aoba, Sendai 980-8578, Japan

Full list of author information is available at the end of the article
}

\section{Springer Open}

(- The Author(s). 2021 Open Access This article is licensed under a Creative Commons Attribution 4.0 International License, which permits use, sharing, adaptation, distribution and reproduction in any medium or format, as long as you give appropriate credit to the original author(s) and the source, provide a link to the Creative Commons licence, and indicate if changes were made. The images or other third party material in this article are included in the article's Creative Commons licence, unless indicated otherwise in a credit line to the material. If material is not included in the article's Creative Commons licence and your intended use is not permitted by statutory regulation or exceeds the permitted use, you will need to obtain permission directly from the copyright holder. To view a copy of this licence, visit http://creativecommons.org/licenses/by/4.0/. 


\section{Introduction}

Hypercalcified demosponges ("sclerosponges" hereinafter), members of the earliest branching metazoan taxon (Porifera), persisted as dominant reef-building marine organisms throughout the Phanerozoic (Vacelet 1985; Reitner and Engeser 1987; Wood 1990; Reitner 1992). The genus Acanthochaetetes Fischer 1970 is present in the fossil record from the Early Cretaceous (Reitner 1992). In modern coral reefs, sclerosponges can be found in cryptic niches of dark environments, unlike zooxanthellate scleractinian corals (Wörheide 1998). Sclerosponges, commonly mushroom-shaped, deposit a calcium carbonate skeleton at a very slow growth rate of mostly fewer than about $2 \mathrm{~mm}$ /year; they can grow for up to several hundred years (Benavides and Druffel 1986; Böhm et al. 1996; Reitner and Gautret 1996; Wörheide et al. 1997; Wörheide 1998; Swart et al. 2002; Fallon et al. 2003; Grottoli et al. 2010).

To elucidate climate change and global warming, environmental proxies such as trees, sediments, and corals are strongly needed for demonstrating temperature variations over the last millennia (PAGES $2 \mathrm{k}$ Consortium 2013; Abram et al. 2016). The stable carbon and oxygen isotope records $\left(\delta^{13} \mathrm{C}\right.$ and $\left.\delta^{18} \mathrm{O}\right)$ of sclerosponges are a proxy for reconstructing dissolved inorganic carbon $\delta^{13} \mathrm{C}$ of seawater (e.g., Böhm et al. 1996; Swart et al. 2010) and seawater temperature and salinity (e.g., Wörheide 1998; Böhm et al. 2000; Moore et al. 2000; Rosenheim et al. 2005a) for the past. Earlier studies have revealed that similarly to corals, the $\delta^{13} \mathrm{C}$ and $\delta^{18} \mathrm{O}$ values of sclerosponges respectively reflect the increase of fossil fuel $\mathrm{CO}_{2}$ in seawater (Böhm et al. 2002; Swart et al. 2010) and interannual climate variation (Swart et al. 2002; Grottoli 2006; Grottoli et al. 2010; Wu and Grottoli 2010). Other minor and trace elements and isotopes can be a proxy for monitoring ocean environments and chemistry (Lazareth et al. 2000; Fallon et al. 2005; Rosenheim et al. 2005b; Ohmori et al. 2014). Particularly, some studies have shown that sclerosponge strontium/calcium $(\mathrm{Sr} / \mathrm{Ca})$ presents some potential for determining seawater paleotemperatures (e.g., Rosenheim et al. 2004; Waite et al. 2018). Its fidelity as a paleoenvironmental proxy has been verified by evaluation and calibration studies of sclerosponges (Böhm et al. 2000; Rosenheim et al. 2005b, 2009; Asami et al. 2020a).

Importantly, sclerosponges can live in environments with less sunlight (e.g., reef caves and overhangs) and at greater water depths of up to several hundred meters in Indo-Pacific tropical regions (e.g., Hartman 1980) and in the Atlantic and Caribbean regions (e.g., Druffel and Benavides 1986; Böhm et al. 1996), unlike zooxanthellate corals and giant clams living in shallow coral reefs. For that reason, their skeletal chemistry can be useful for elucidating the vertical variations of physical and chemical parameters of seawater and for generating their several-centuries-long time series that overlap with and extend beyond instrumental oceanographic data. However, sclerosponge-based climate reconstructions over a hundred years are extremely few relative to those of corals. Moreover, they have not yet been extracted from the northwestern subtropical Pacific.

We first generated > 100-year-long multiple proxy records of $\delta^{13} \mathrm{C}, \delta^{18} \mathrm{O}$, and elements/Ca ratios, $\mathrm{Sr} / \mathrm{Ca}$, barium $/ \mathrm{Ca}(\mathrm{Ba} / \mathrm{Ca})$, lead/Ca $(\mathrm{Pb} / \mathrm{Ca})$, and uranium/Ca $(\mathrm{U} / \mathrm{Ca})$, in living sclerosponges (Acanthochaetetes wellsi Hartman and Goreau 1975) collected from the Ryukyu Islands of southwestern Japan. Based on radiocarbon and $\delta^{13} \mathrm{C}$ results, near-annually resolved time series of the geochemical records were established for the last one hundred years and more, which are expected to be useful for paleoclimate archives such as corals. The study results emphasize that the geochemical time series show secular decade-scale variations of ocean environments in the subtropical Northwest Pacific.

\section{Materials and methods}

\subsection{Study site and modern environment}

The study sites are located off the southern coast of Miyako Island and at Manza Cape around the western coast of Okinawa Island in the Ryukyu Islands of southwestern Japan (Fig. 1). The northward-flowing warm Kuroshio current (the western North Pacific current) passes along the Ryukyu Islands, which has allowed the development of coral reefs with high biodiversity in the islands. The Kuroshio current, the strong northwestern component of the subtropical North Pacific gyre, advects a large amount of heat from the tropics to northern mid-latitudes. The climate is subtropical, with atmospheric temperatures of $17.6-28.5{ }^{\circ} \mathrm{C}$ and $16.5-28.6{ }^{\circ} \mathrm{C}$ and an annual mean of $23.4{ }^{\circ} \mathrm{C}$ and $22.8{ }^{\circ} \mathrm{C}$ at Miyako and Okinawa Islands for 1961-2015 (Japan Meteorological Agency; http://www.jma.go.jp/jma/indexe.html). The mean annual precipitation is greater than 2000 $\mathrm{mm}$ /year, with a rainy season (May-June) and typhoon season (August-September) at the two sites. Sea surface temperatures (SST) with a $2^{\circ}-2^{\circ}$ grid for 1961-2015, available at the study sites (NOAA NCDC ERSST ver. 3b, http://iridl.ldeo.columbia.edu/), show variation of $22.9-29.1{ }^{\circ} \mathrm{C}$ and $21.8-28.9{ }^{\circ} \mathrm{C}$ with annual means of $26.1{ }^{\circ} \mathrm{C}$ and $25.4^{\circ} \mathrm{C}$ in Miyako $\left(23^{\circ}-25^{\circ} \mathrm{N}, 125^{\circ}-127^{\circ} \mathrm{E}\right)$ and Okinawa $\left(25^{\circ}-27^{\circ} \mathrm{N}, 127^{\circ}-129^{\circ} \mathrm{E}\right)$, respectively. According to monthly average data available from the Japan Oceanographic Data Center (JODC) for 19062003 (http://www.jodc.go.jp/), the sea surface salinity (SSS) varies 34.3-34.9 and 34.1-35.0, respectively, with annual means of 34.7 and 34.6 at Miyako $\left(24^{\circ}-25^{\circ} \mathrm{N}\right.$, $\left.125^{\circ}-126^{\circ} \mathrm{E}\right)$ and Okinawa $\left(26^{\circ}-27^{\circ} \mathrm{N}, 127^{\circ}-128^{\circ} \mathrm{E}\right)$. 


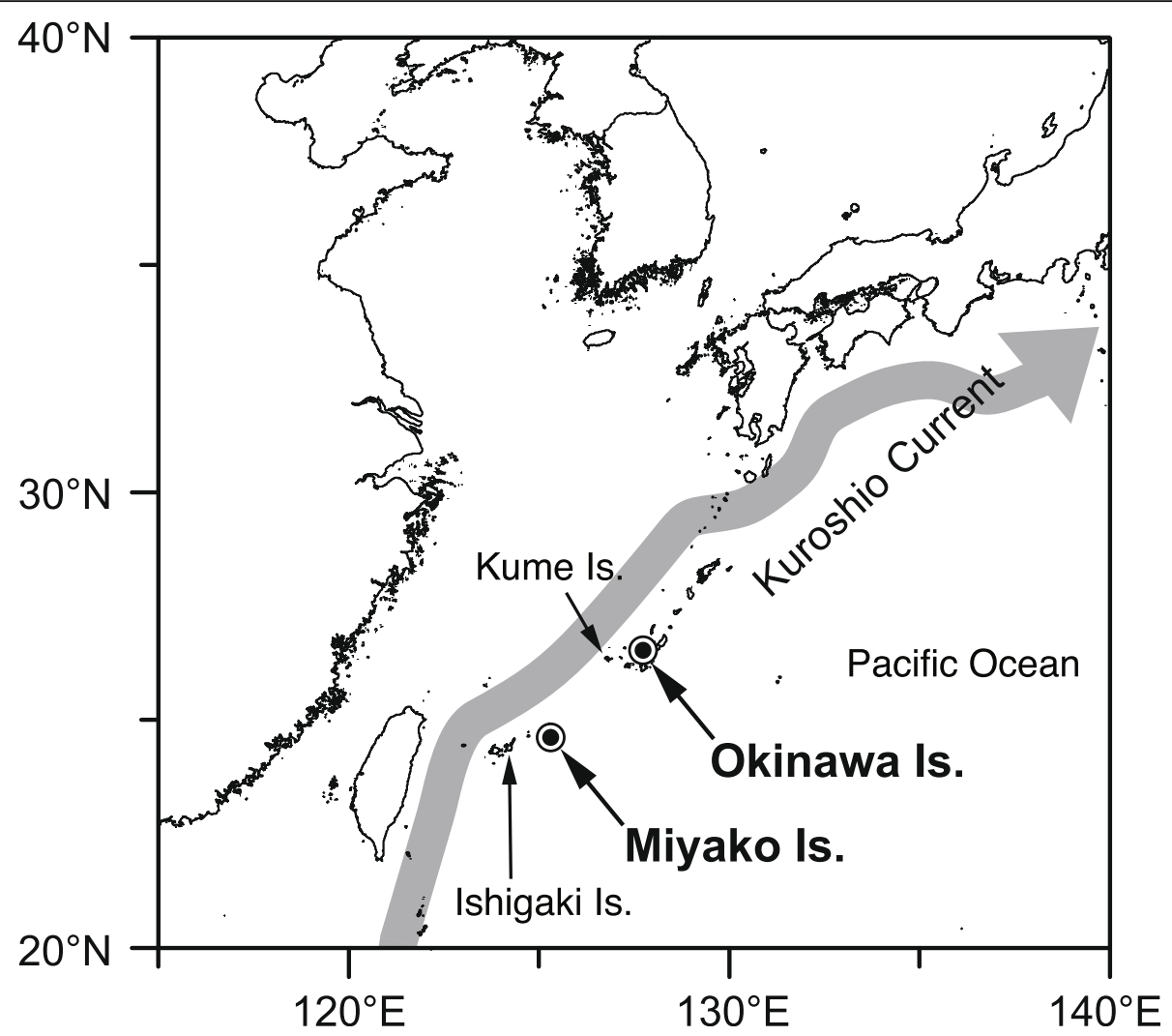

Fig. 1 Map of eastern Asian and the northwestern Pacific regions showing the locations of Miyako Island and Okinawa Island (this study) and Ishigaki Island (Abe et al. 2009; Hirabayashi et al. 2017) and Kume Island (Ohmori et al. 2014) discussed in the text

\subsection{Samples}

The sclerosponges (Acanthochaetetes wellsi) examined in this study were growing on the wall in a dark submarine crevasse (Miyako Island) and cave (Okinawa Island) of outer reef edges. In June 2012, a living sclerosponge sample (SMJ-2-S1) was collected at $10.2 \mathrm{~m}$ water depth from Miyako Island (24 $\left.42^{\prime} 24.2^{\prime \prime} \mathrm{N}, 125^{\circ} 19^{\prime} 02.6^{\prime \prime} \mathrm{E}\right)$ (Figs. 1 and 2). The sample SMJ-2-S1 is $7 \mathrm{~cm}$ in height, $21 \mathrm{~cm}$ in length of the major axis, and $18 \mathrm{~cm}$ in length of the minor axis. In October 2015, a living sclerosponge sample (MNZ-S1) was collected at $2 \mathrm{~m}$ water depth from Okinawa Island $\left(26^{\circ} 30^{\prime} 14.9^{\prime \prime} \mathrm{N}, 127^{\circ} 50^{\prime} 52.5^{\prime \prime}\right.$ E) (Figs. 1 and 2). The sample MNZ-S1 is $9 \mathrm{~cm}$ in height, $19 \mathrm{~cm}$ in length of the major axis, and $18 \mathrm{~cm}$ in length of the minor axis. The skeletal surfaces (tissue layer zones) of samples were mostly light brown or orange, which has a thickness of less than $2 \mathrm{~mm}$. The samples were well rinsed ultrasonically with milli-Q water (resistance $=18.2 \mathrm{M} \Omega \cdot \mathrm{cm}$; Millipore Corp.). They were then dried.

The sclerosponge samples were slabbed to $3 \mathrm{~mm}$ thickness parallel to the axis of skeletal growth. Xradiographs were taken under exposure conditions of 30 $\mathrm{kV}, 3 \mathrm{~mA}$, and a distance of $53 \mathrm{~cm}$ between a lamp and a film with exposure time of 15-60 s, using soft X-ray film shooting equipment (Soft X-Ray Sofron SRO-405A; Soken Co., Ltd.) and a computed radiographic reader (FCR PRIMA T2; FUJI FILM Corp.) at the University of the Ryukyus (UR). The X-radiographic images of the samples showed skeletal banding comprising alternating high-density (dark) and low-density (light) bands (Fig. 2). Powder subsamples for geochemical analyses were taken every $1 \mathrm{~mm}$ along the skeletal growth direction manually using a pre-cleaned diamond drill, roughly corresponding to the annual sampling resolution. To determine the time series of geochemical records, radiocarbon values $\left(\Delta^{14} \mathrm{C}, \%\right.$ o) of 13 subsamples along the growth direction of the SMJ-2-S1 sample were analyzed by Paleo-Lab Co. Ltd., Japan (Supplementary Table S1). The data are reported in terms of deviation from the activity of the pre-industrial wood standard (Stuiver and Polach 1977), which is corrected for isotope fractionation to a $\delta^{13} \mathrm{C}$ value of $-25.0 \%$. In addition, powder subsamples were taken from different portions of the skeleton surface to evaluate within-skeleton variations in the geochemistry, following the method described by Asami et al. (2020a).

\subsection{Skeletal structures}

To check the mineralogy and preservation state of the skeleton, the fragments were examined using X-ray 


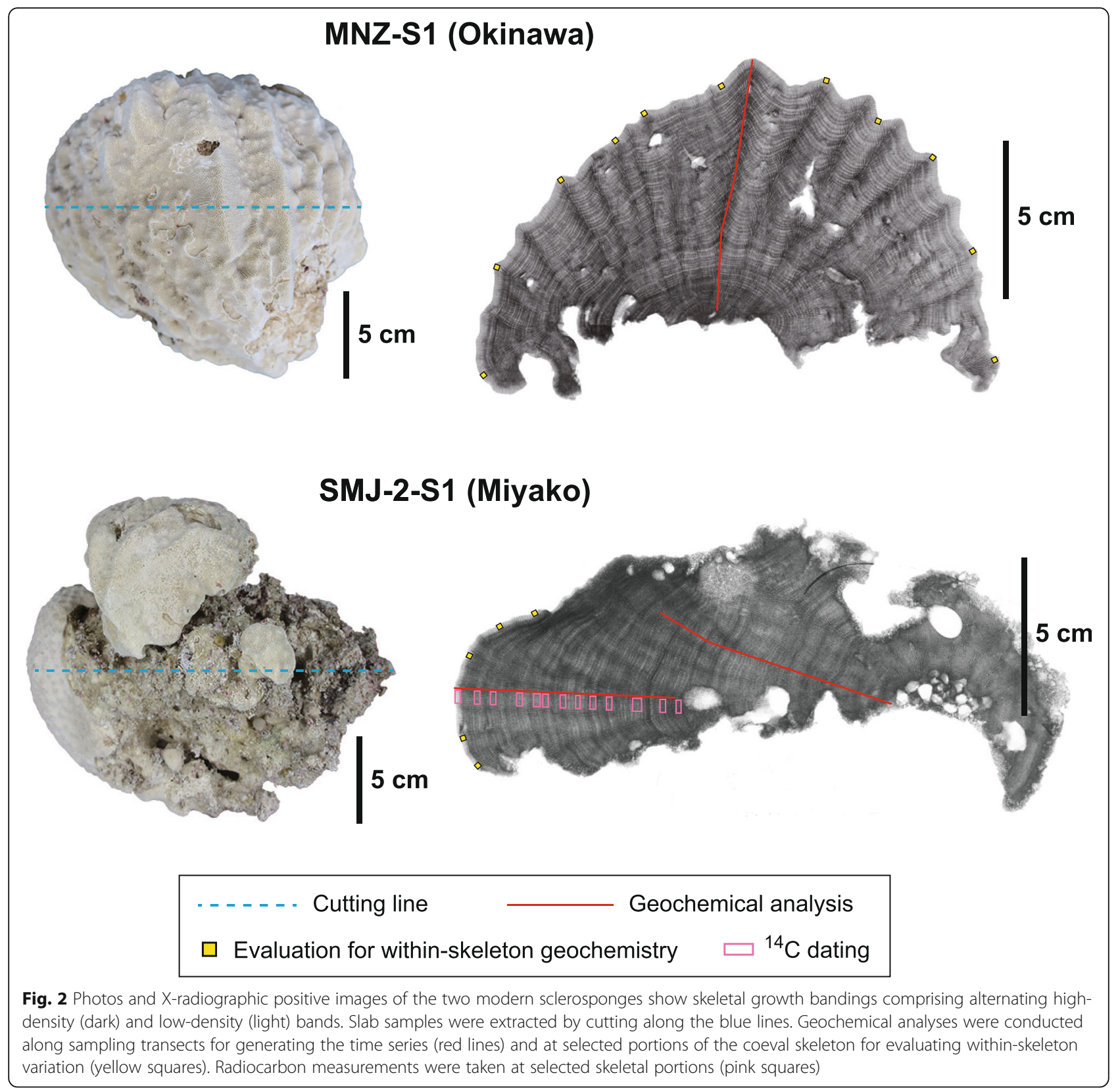

diffraction (XRD) analysis and scanning electron microscopy (SEM), following the methods reported by Asami et al. $(2015,2020 a)$. At UR, XRD analysis was conducted using a multipurpose XRD device (RINT Ultima/PC; Rigaku Corp.) to test for mineralogy. After powdered samples were mounted on well-cleaned glass slides with $\mathrm{HCl}$, ethanol, and milli- $\mathrm{Q}$ water, they were analyzed using $\mathrm{Cu} \mathrm{K} \alpha$ radiation $(40 \mathrm{kV}, 30 \mathrm{~mA})$ by scanning from $20^{\circ}$ to $37^{\circ}$ at a $2 \theta$ angle at $0.02^{\circ}$ steps. A microscope (TM3030; Hitachi High-Tech. Corp.) was used for SEM imaging of the skeleton. Also, XRD analysis revealed that the $A$. wellsi samples consisted of high-Mg calcite with $20.1 \mathrm{~mol} \% \mathrm{Mg}$ for SMJ-2-S1 and $17.3 \mathrm{~mol} \% \mathrm{Mg}$ for
MNZ-S1, consistent with data reported from earlier studies (Reitner and Engeser 1987; Reitner and Gautret 1996; Grottoli et al. 2010). The SEM observations revealed that skeletal aspects of our sclerosponge samples (Fig. 3) closely resemble those found in earlier studies (Reitner and Engeser 1987; Reitner et al. 1997; Gilis et al. 2013), clearly showing a typical macrostructure organization with vertical calicles subdivided by horizontal tabulae and a microstructure of high-Mg calcite skeleton. Additionally, results confirmed that the samples had a well-preserved skeleton without physical evidence of diagenetic alteration, such as overgrowth of inorganically precipitated secondary cement, traces of dissolution, 


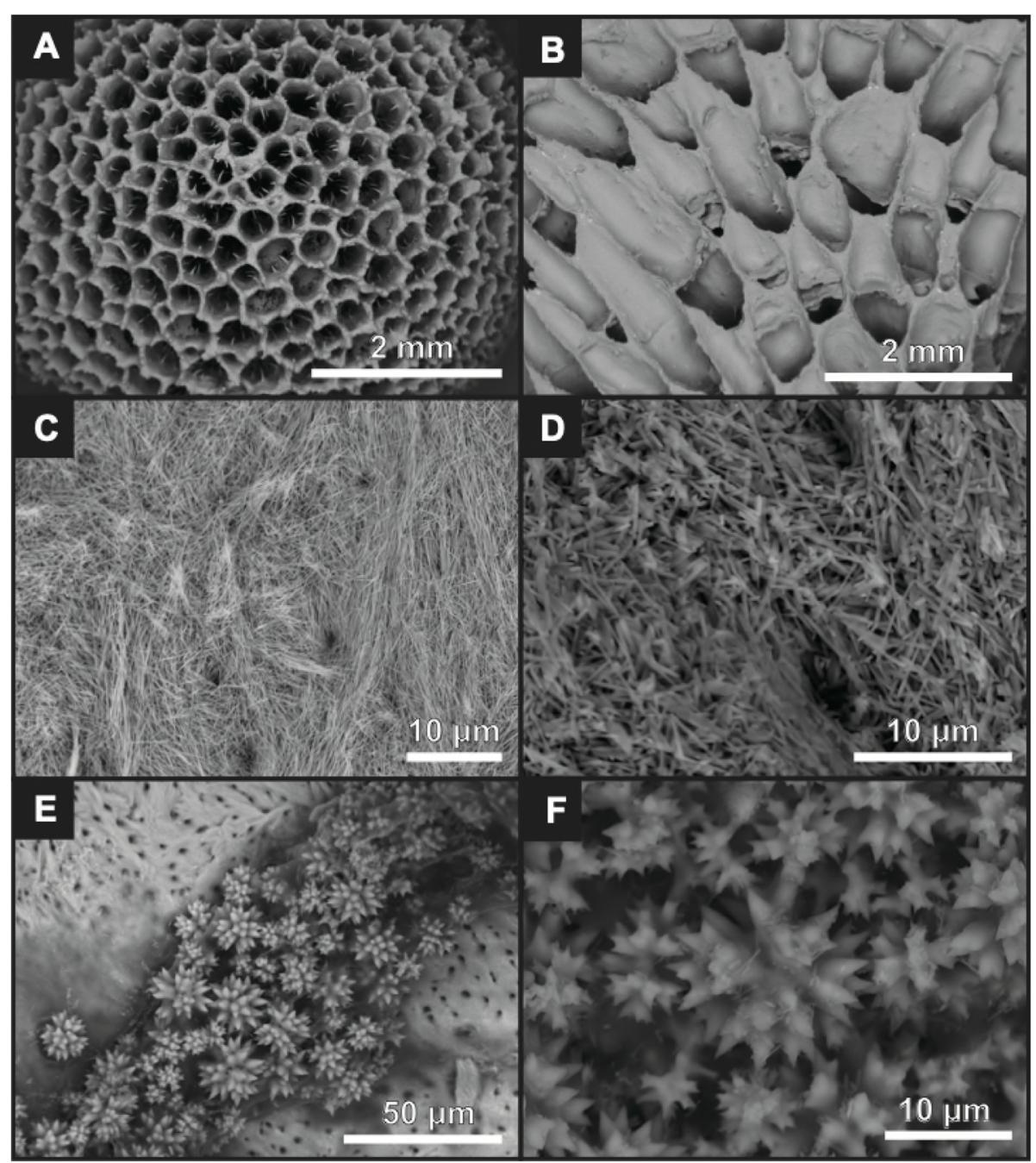

Fig. 3 Scanning electron micrograph images of sclerosponges. A well-preserved pristine calcite skeleton is visible. A and B Macrostructural organization of high-Mg calcite skeleton with vertical calicles subdivided by horizontal tabulae. C and $\mathbf{D}$ Lamellar microstructure of high-Mg calcite skeleton, the secondary structure of the tabulae and coatings of the tubes, randomly oriented single crystals. $\mathbf{E}$ and $\mathbf{F}$ Spicular skeleton and spiraster microscleres

or bioerosion. Consequently, these results indicate that A. wellsi samples used for this study can retain pristine calcite skeleton with original values of isotope composition and elemental concentrations.

\subsection{Stable isotope analyses}

Stable carbon $\left(\delta^{13} \mathrm{C}\right)$ and oxygen $\left(\delta^{18} \mathrm{O}\right)$ isotope analyses of calcium carbonate $(0.14-0.16 \mathrm{mg})$ were conducted using a continuous-flow isotope ratio mass spectrometer attached to a Gasbench II and a GC-PAL auto-sampler (Delta V Advantage; ThermoFisher Scientific Inc.) at UR, following the method presented by Asami et al. $(2015,2020 a)$. Isotopic ratios were reported in conventional $\delta$ notation relative to Vienna Pee Dee Belemnite (VPDB). External precision $(1 \sigma, N=190)$ throughout the entire analysis was $\pm 0.04 \%$ and $\pm 0.06 \%$ for $\delta^{13} \mathrm{C}$ and $\delta^{18} \mathrm{O}$. Accuracy of the measurements of sclerosponge samples was evaluated based on replicates of IAEA CO1 calcite standard, yielding average $\delta^{13} \mathrm{C}$ and $\delta^{18} \mathrm{O}$ values of $2.46 \pm 0.05 \%$ and $-2.41 \pm 0.06 \%$ o $(N=27)$, which respectively show excellent agreement with recommended values.

\subsection{Elements/Ca analyses}

Elements/Ca ratios $(\mathrm{Sr} / \mathrm{Ca}, \mathrm{Ba} / \mathrm{Ca}, \mathrm{Pb} / \mathrm{Ca}, \mathrm{U} / \mathrm{Ca})$ were analyzed using an inductively coupled plasma-mass spectrometer (XSeries II; ThermoFisher Scientific Inc.) at UR, fundamentally following the method reported by Asami et al. (2009, 2020a). Each sclerosponge powder sample (approx. $0.15 \mathrm{mg}$ ) was dissolved in $4.5 \mathrm{~mL}$ of 0.5 mol/L high-purity $\mathrm{HNO}_{3}$ diluted with ultrapure Milli-Q water. Each seawater sample of $125 \mu \mathrm{L}$ was diluted 80 
times with high-purity $\mathrm{HNO}_{3}$ and ultrapure Milli-Q water. Internal standard elements $(\mathrm{Sc}, \mathrm{Y}$, and $\mathrm{Yb})$ were added to all the solutions to produce equal concentrations to control matrix effects and to correct for instrumental noise. Solutions were analyzed for ${ }^{43} \mathrm{Ca}$, ${ }^{44} \mathrm{Ca},{ }^{45} \mathrm{Sc},{ }^{87} \mathrm{Sr},{ }^{88} \mathrm{Sr},{ }^{89} \mathrm{Y},{ }^{137} \mathrm{Ba},{ }^{138} \mathrm{Ba},{ }^{172} \mathrm{Yb},{ }^{208} \mathrm{~Pb}$, and ${ }^{238} \mathrm{U}$. Measurements were conducted in triplicate. Calibrations of the five gravimetric standard solutions yielded high correlation coefficients of $r>0.99998$ for $\mathrm{Ca}$ and $\mathrm{Sr}$ and of $r>0.99995$ for $\mathrm{Ba}, \mathrm{Pb}$, and $\mathrm{U}$. A reference solution, matched gravimetrically to the Ca concentration of the average sclerosponge sample solutions, was measured at intervals of three samples to correct instrumental drift. Based on replicate measurements of the solution of carbonate reference material JCp-1 (Okai et al. 2002), external precisions for $\mathrm{Sr} / \mathrm{Ca}, \mathrm{Ba} / \mathrm{Ca}, \mathrm{Pb} / \mathrm{Ca}$, and $\mathrm{U} / \mathrm{Ca}$ determinations were better than $0.30 \%, 1.7 \%$, $4.1 \%$, and $0.77 \%$ relative standard deviations $(N=166)$. The measurement values of samples were calibrated using the widely accepted values of Hathorne et al. (2013).

\section{Results and discussion}

\subsection{Within-skeleton variations and comparison with}

\section{equilibrium calcite}

The within-skeleton variations of geochemical components in an $A$. wellsi specimen were estimated at the coevally precipitated skeleton (Fig. 4A). The standard deviations $(1 \sigma)$ of geochemical analyses of SMJ-2-S1 and MNZ-S1 samples were, respectively, $\pm 0.049 \%$ and \pm $0.039 \%$ for $\delta^{13} \mathrm{C}, \pm 0.056 \%$ and $\pm 0.093 \%$ for $\delta^{18} \mathrm{O}$, \pm 0.061 and $\pm 0.045 \mathrm{mmol} / \mathrm{mol}$ for $\mathrm{Sr} / \mathrm{Ca}$ (RSD, $3.9 \%$ and $3.6 \%$ ), \pm 0.54 and $\pm 0.17 \mu \mathrm{mol} / \mathrm{mol}$ for $\mathrm{Ba} / \mathrm{Ca}$ (RSD, $7.7 \%$ and $9.9 \%$ ), \pm 172 and $\pm 253 \mathrm{nmol} / \mathrm{mol}$ for $\mathrm{Pb} / \mathrm{Ca}$ (RSD, $8.1 \%$ and $7.8 \%$ ) and \pm 0.021 and $\pm 0.012 \mu \mathrm{mol} / \mathrm{mol}$ for
$\mathrm{U} / \mathrm{Ca}$ (RSD, $8.5 \%$ and $4.3 \%$ ). The variations of sclerosponge geochemical records are small among all skeletal portions, with no marked trend, except for $\mathrm{Ba} / \mathrm{Ca}$ and $\mathrm{Pb} / \mathrm{Ca}$, which accord well with those of Astrosclera willeyana sclerosponge reported by Asami et al. (2020a). These results reflect that within-skeleton variations in $\delta^{13} \mathrm{C}, \delta^{18} \mathrm{O}, \mathrm{Sr} / \mathrm{Ca}$, and $\mathrm{U} / \mathrm{Ca}$ are slight for the A. wellsi species.

To evaluate the fidelity of $A$. wellsi as a paleoenvironmental proxy, we compared our data with the $\delta^{13} \mathrm{C}$ and $\delta^{18} \mathrm{O}$ values of calcite that is precipitated inorganically in isotopic equilibrium with seawater at the sclerosponge growth site: so-called equilibrium calcite. The $\delta^{13} \mathrm{C}$ values of the equilibrium calcites were estimated using DIC $\delta^{13} \mathrm{C}$ of seawater, the carbon-isotope fractionation factors among $\mathrm{CO}_{2}$ species (Zhang et al. 1995), and the calcite- $-\mathrm{HCO}_{3}{ }^{-}$enrichment factor (1.0 \pm 0.2\%; Romanek et al. 1992). Because of the lack of data on DIC $\delta^{13} \mathrm{C}$ of seawater around the study sites, the annual mean DIC $\delta^{13} \mathrm{C}$ value is assumed to fall within a range of $0.58 \%$ in November to $0.78 \%$ in August, estimated respectively using two significant relations from west of Okinawa Island (Takayanagi et al. 2012) and southeast of Okinawa Island (Suzuki et al. 2009). Consequently, the $\delta^{13} \mathrm{C}$ values of the equilibrium calcites are expected to be roughly $1.6-2.2 \%$ (Fig. $4 \mathrm{~B}$ ). The $\delta^{18} \mathrm{O}$ values were calculated using an equation derived from laboratory synthesis experiments of calcite (Kim and O'Neil 1997), with correction for $\mathrm{MgCO}_{3}$ in calcite (Tarutani et al. 1969). The annual mean seawater temperatures of $26.3^{\circ} \mathrm{C}$ for $2010-2012$ in Miyako Island and $25.2{ }^{\circ} \mathrm{C}$ for $2013-2015$ in Okinawa Island were used from the ERSST v3b gridded dataset. The seawater $\delta^{18} \mathrm{O}$ values of $0.35-0.52 \%$ and $0.26-0.56 \%$ o were estimated respectively for Miyako Island and Okinawa Island from
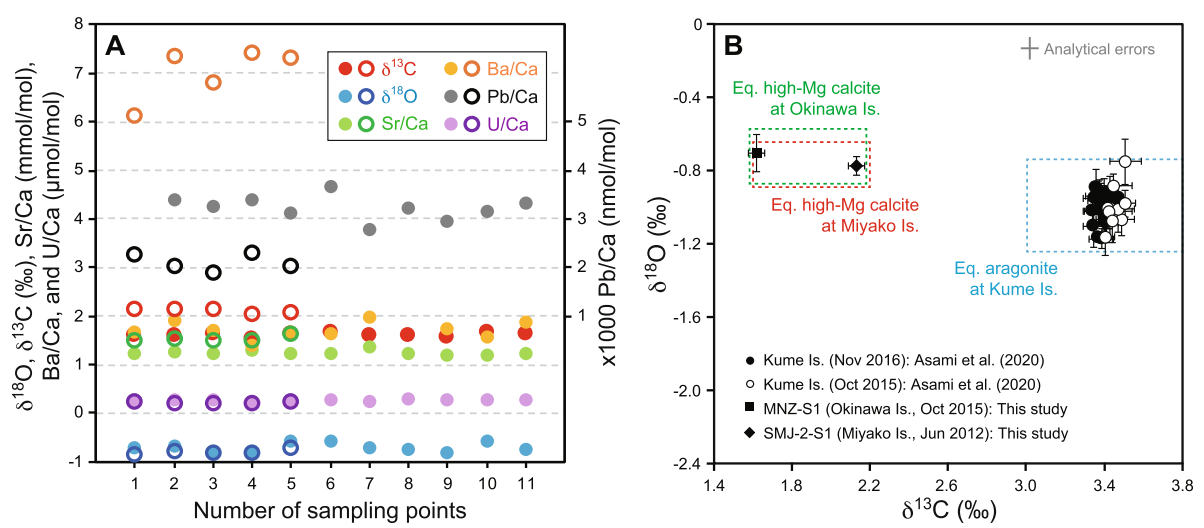

Fig. 4 A Within-skeleton variations in the geochemistry of the SMJ-2-S1 (open circles) and MNZ-S1 (dotted circles) samples. The Ba/Ca and Pb/Ca data at the respective sampling point of $X=8$ and $X=1$ for the MNZ-S1 sample were evaluated as outliers based on the Smirnov-Grubbs test ( $p$ $<0.025)$. B Scatter plot of $\delta^{13} \mathrm{C}$ and $\delta^{18} \mathrm{O}$ averages with $1 \sigma$ standard deviations of coeval skeletal portions in individual samples. Red and green areas are shown respectively as estimated ranges of isotopically equilibrium calcite precipitated at the study sites of Miyako and Okinawa Islands. For comparison, aragonite sclerosponge (Astrosclera willeyana) data and an equilibrium aragonite estimate are also shown (Asami et al. 2020a) 
JODC salinity data using a relation for coral reef environment in Ishigaki Island in the southern Ryukyus (Abe et al. 2009). Results show that the $\delta^{18} \mathrm{O}$ values of equilibrium high-Mg calcites precipitated at the study sites are expected to fall within a range of $-0.85 \%$ to $-0.67 \%$ in Miyako Island and from -0.88 to $-0.58 \%$ in Okinawa Island (Fig. 4B). Consequently, the $\delta^{13} \mathrm{C}$ and $\delta^{18} \mathrm{O}$ values of coeval skeletal portions of our $A$. wellsi samples are consistent with those of equilibrium calcites, as same as the findings for A. wellsi (Böhm et al. 1996; Grottoli et al. 2010) and A. willeyana (Asami et al. 2020a). These lines of evidence document that our A. wellsi samples can be suitable for the paleoenvironmental reconstruction study because they probably have a little vital or biological effect on skeletal geochemistry.

\subsection{Time series determination}

To convert sclerosponge geochemical records from the depth domain to the time domain, an age model was established using our $\Delta^{14} \mathrm{C}$ results of 13 subsamples along the growth direction of the SMJ-2-S1 sample (Table S1 and Fig. 2) and earlier reported highresolution data of accurately dated coral skeleton collected at a $5 \mathrm{~m}$ water depth from Ishigaki Island (Hirabayashi et al. 2017) in the Ryukyu region (Fig. 1). It is assumed for this study that a difference in local ${ }^{14} \mathrm{C}$ reservoir effects between Miyako Island and Ishigaki Island can be ignored because the two sites are separated by only a short distance (approx. $120 \mathrm{~km}$ ). Moreover, they are located at almost equal water depth in the same oceanographic setting in the Ryukyu Islands. Figure 5 depicts a comparison showing good consistency between the two $\Delta{ }^{14} \mathrm{C}$ profiles for $1947-1997$, which yields an age model with a pretty high correlation $(r=0.999)$ under the condition that the skeletal growth rate of sclerosponge is constant at $1.02 \mathrm{~mm} /$ year. Our growth rate estimate accords with earlier studies for the same species: A. wellsi $(1.355 \mathrm{~mm} /$ year, Grottoli et al. 2010; $0.80-0.85 \mathrm{~mm} /$ year, Ohmori et al. 2014). Applying the age model to the data before 1940, a 130-year-long (1880-2012 AD) time series of the geochemistry was generated from the SMJ-2-S1 sample. For age determination of MNZ-S1 sample, the $\delta^{13} \mathrm{C}$ profiles were used for this study, the method of which is based on evidence that the $\delta^{13} \mathrm{C}$ records of our two samples clearly exhibited a typical decreasing trend associated with the anthropogenically derived Suess effects as well as those shown in corals and other sclerosponges (see details presented in the next section). The decreasing trend of the depth domain MNZ-S1 $\delta^{13} \mathrm{C}$ record under the condition that the skeletal growth rate is constant at 1.42 $\mathrm{mm}$ /year corresponded well with that of the SMJ-2-S1 $\delta^{13} \mathrm{C}$ time series since 1960 , yielding a high correlation coefficient of 0.99 (Supplementary Figure S1). Based on those results, it can be estimated that the sclerosponge MNZ-S1 has grown for about 55 years. We identified $65 \pm 5$ pairs of skeletal density bandings in selected three transects near the geochemical profile of the Xradiographic image of MNZ-S1 using software (ImageJ64), possibly implying that the growth bandings might have been formed annually (Fig. 2). However, the overestimation of $10 \pm 5$ pairs of density bandings may indicate that the MNZ-S1 sclerosponge occasionally has seasonally formed growth bandings. Therefore, the skeletal bandings of sclerosponges cannot be used for age determination in this study, like corals, because further validation studies using ultra-high resolution laser ablation analyses are needed.
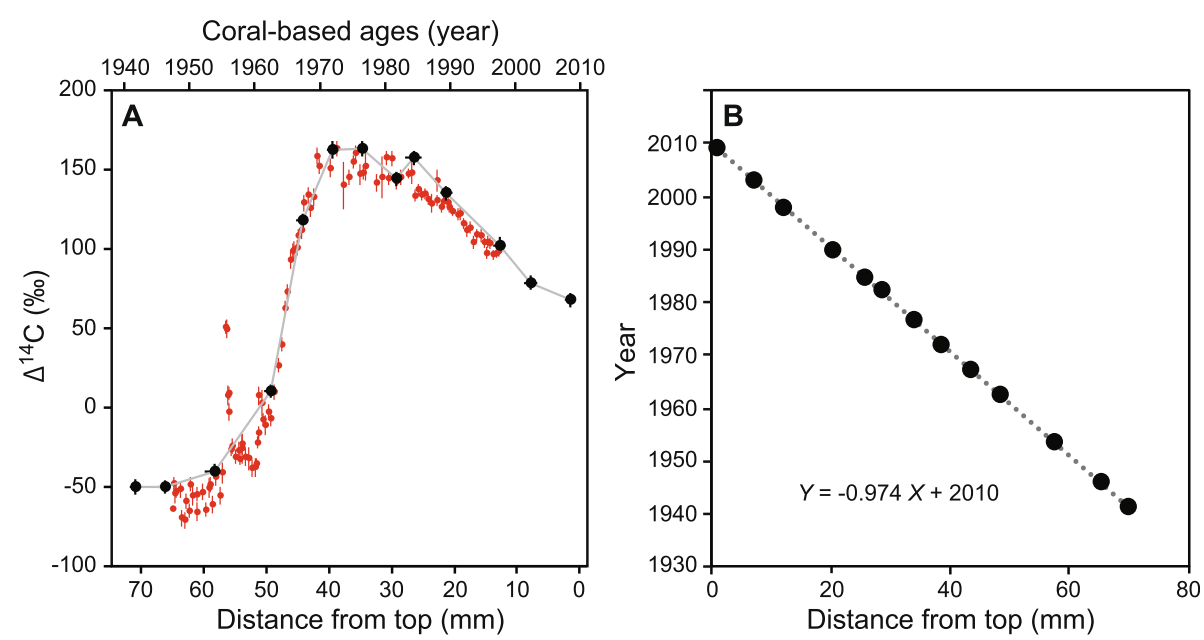

Fig. 5 A Comparison of the depth domain profile of radiocarbon $\left(\Delta^{14} \mathrm{C}\right)$ data of the SMJ-2-S1 sclerosponge with a coral-derived time series from Ishigaki Island in the southern part of Ryukyu Islands (Hirabayashi et al. 2017). B Established age model in this study at the assumption that sclerosponge skeletal rate has been constant 


\subsection{Anthropogenic signatures: carbon isotope}

The $\delta^{13} \mathrm{C}$ values of SMJ-2-S1 and MNZ-S1 samples were $2.06 \%$ to $3.49 \%$ or $1880-2012$ and were $1.54 \%$ o to $3.01 \%$ for $1960-2015$ (Fig. 6). The near-annual resolved $\delta^{13} \mathrm{C}$ time series of the SMJ-2-S1 sample showed decreasing trends at low $(-0.0043 \%$ oyear $)$ and high $(-0.023 \%$ o/year $)$ rates, respectively before and after 1960 (Table 1; Fig. 6). The latter rate is identical to that of the MNZ-S1 sample (-0.024\%o/year). Such a typical decreasing trend found in this study probably reflects the Suess effect, which is widely accepted as a result of the burning of ${ }^{12} \mathrm{C}$-enriched fossil fuels (Keeling et al. 1979; Quay et al. 1992). The effect has decreased $\delta^{13} \mathrm{C}$ of dissolved inorganic carbon (DIC) in seawater since the midtwentieth century because of the accelerated increase of anthropogenically derived $\mathrm{CO}_{2}$ with isotopically low $\delta^{13} \mathrm{C}$ values into the ocean from the atmosphere, results of which are recorded in corals and sclerosponges in the Pacific and Atlantic Oceans (e.g., Böhm et al. 2002; Asami et al. 2005; Swart et al. 2010). The post-1960 rates of decrease of our sclerosponge $\delta^{13} \mathrm{C}$ records are close to that of the northwestern tropical Pacific coral for 1960-2000 (Asami et al. 2005) (Fig. 6) and of atmospheric $\mathrm{CO}_{2}$ at Hawaii for 2000-2016 (derived from the Scripps $\mathrm{CO}_{2}$ Program initiated in 1956 by Keeling CD). It is fascinating that the rate of decrease of our $\delta^{13} \mathrm{C}$ records $(-0.0043 \%$ /year $)$ for $1880-1960$ was similar to those $(-0.0033$ to $-0.0060 \%$ /year $)$ of the tropical Atlantic sclerosponges (Lazareth et al. 2000; Böhm et al. 2002; Swart et al. 2002), but our results ( -0.019 and $-0.020 \%$ opear) were slightly higher than those $(-0.006$ to $-0.017 \%$ o/year) for 1960-1992 (Table 1; Fig. 6). These results indicate that the accelerated increase in anthropogenic $\mathrm{CO}_{2}$ with low $\delta^{13} \mathrm{C}$ values has been about 1.4 times greater in the surface ocean around Miyako and Okinawa Islands of the subtropical Northwest Pacific than in the Caribbean Sea of the tropical Atlantic since the mid-twentieth century. The difference in the decreasing rates of sclerosponge $\delta^{13} \mathrm{C}$ records between the two regions is consistent with that in annual mean sea-air $\mathrm{CO}_{2}$ flux (Takahashi et al. 2009), showing that $\mathrm{CO}_{2}$ sink is significantly higher in the northwestern Pacific region, especially during winter than in the Caribbean Sea.

\subsection{Seawater temperature variations: oxygen isotope, $\mathrm{Sr} /$ \\ $\mathrm{Ca}$, and $\mathrm{U} / \mathrm{Ca}$}

The respective $\delta^{18} \mathrm{O}, \mathrm{Sr} / \mathrm{Ca}$, and $\mathrm{U} / \mathrm{Ca}$ values of the SMJ-2-S1 sample for $1880-2012$ were $-1.11 \%$ to $-0.72 \%$, 1.32 to $1.70 \mathrm{mmol} / \mathrm{mol}$, and 0.22 to $0.27 \mu \mathrm{mol} /$ $\mathrm{mol}$ and averaged $-0.90 \%, 1.52 \mathrm{mmol} / \mathrm{mol}$, and 0.24 $\mathrm{nmol} / \mathrm{mol}$ (Fig. 7). The respective values of the MNZ-S1 sample for $1960-2015$ were $-1.19 \%$ o to $-0.48 \%$, 1.32 to $1.51 \mathrm{mmol} / \mathrm{mol}$, and 0.26 to $0.34 \mu \mathrm{mol} / \mathrm{mol}$ and averaged $-0.75 \%$, $1.39 \mathrm{mmol} / \mathrm{mol}$, and $0.29 \mu \mathrm{mol} / \mathrm{mol}$. The $\delta^{18} \mathrm{O}$, $\mathrm{Sr} / \mathrm{Ca}$, and $\mathrm{U} / \mathrm{Ca}$ time series accord well with long-term variations and trends of the seawater temperatures on decadal and multi-decadal timescales. Some inconsistency exists between the SSTs and sclerosponge geochemical records on annual-to-interannual timescales, the reason of which is explainable by the errors (probably less than \pm 2 years) of age determination on the assumption that the skeletal growth rate is constant. Therefore, to discuss seasonal, annual, and interannual resolved climate signals, specifying annually formed growth layers in sclerosponge skeleton in combination with high-resolution ${ }^{14} \mathrm{C}$ measurements will be useful.

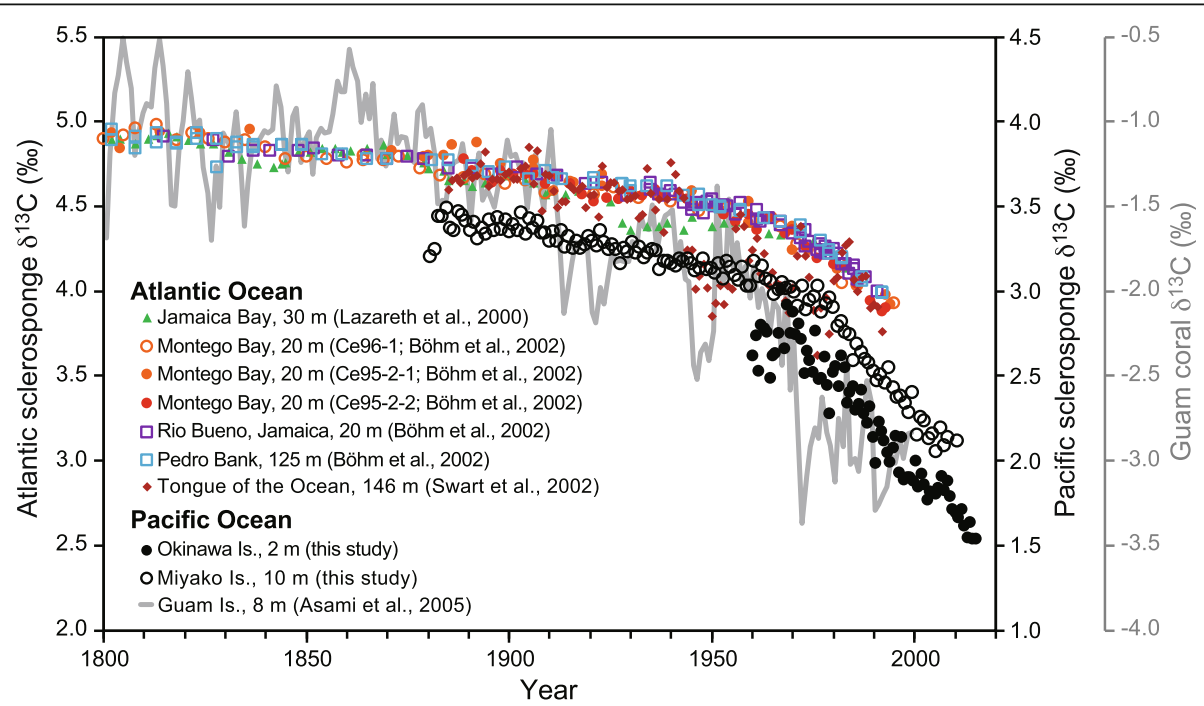

Fig. 6 Time series of sclerosponge $\delta^{13} \mathrm{C}$ from Miyako and Okinawa Islands in the northwestern subtropical Pacific compared to earlier published data from sclerosponges in the tropical Atlantic (Lazareth et al. 2000; Böhm et al. 2002; Swart et al. 2002) and a Porites sp. coral in the western tropical Pacific (Asami et al. 2005) 
Table 1 Decreasing trends estimated from sclerosponge $\delta^{13} \mathrm{C}$ records since 1800

\begin{tabular}{|c|c|c|c|c|c|c|c|c|}
\hline & \multirow[t]{3}{*}{ Locality } & \multirow{3}{*}{$\begin{array}{l}\text { Water } \\
\text { depth } \\
\text { (m) }\end{array}$} & \multicolumn{3}{|c|}{ Before 1960} & \multicolumn{3}{|l|}{ After 1960} \\
\hline & & & \multirow[t]{2}{*}{ Period } & \multicolumn{2}{|c|}{$\delta^{13} \mathrm{C}$ slope for $1880-1960$} & \multirow[t]{2}{*}{ Period } & \multicolumn{2}{|c|}{$\delta^{13} \mathrm{C}$ slope for $1960-1992$} \\
\hline & & & & (\%o/year) & (\%o/year) & & (\%o/year) & (\%o/year) \\
\hline \multicolumn{9}{|l|}{ Pacific Ocean (this study) } \\
\hline MNZ-S1 & Okinawa Is. & 2 & & & & $1960-2015$ & -0.024 & -0.019 \\
\hline SMJ-2-S1 & Miyako Is. & 10 & 1880-1960 & -0.0043 & -0.0043 & 1960-2012 & -0.023 & -0.020 \\
\hline \multicolumn{9}{|c|}{ Atlantic Ocean (Carribean Sea) } \\
\hline Lazareth et al. (2000) & Jamaica Bay & 30 & 1800-1960 & -0.0037 & -0.0049 & 1960-1983 & -0.010 & \\
\hline $\begin{array}{l}\text { Böhm et al. (2002) } \\
\text { (Ce96-1) }\end{array}$ & Montego Bay & 20 & $1800-1960$ & -0.0031 & -0.0033 & 1960-1995 & -0.015 & -0.015 \\
\hline $\begin{array}{l}\text { Böhm et al. (2002) } \\
\text { (Ce95-2-1) }\end{array}$ & Montego Bay & 20 & 1800-1960 & -0.0030 & -0.0048 & 1960-1994 & -0.016 & -0.016 \\
\hline $\begin{array}{l}\text { Böhm et al. (2002) } \\
\text { (Ce95-2-2) }\end{array}$ & Montego Bay & 20 & 1889-1960 & -0.0040 & & 1960-1993 & -0.017 & -0.017 \\
\hline Böhm et al. (2002) & Rio Bueno, Jamaica & 20 & 1827-1960 & -0.0040 & -0.0060 & 1960-1986 & -0.013 & \\
\hline Böhm et al. (2002) & Pedro Bank & 125 & 1800-1960 & -0.0026 & -0.0038 & 1960-1992 & -0.017 & -0.017 \\
\hline Swart et al. (2002) & Tongue of the Ocean & 146 & $1886-1960$ & -0.0079 & & 1960-1992 & -0.006 & -0.006 \\
\hline
\end{tabular}

Since 1960, SSTs have increased in the Miyako and Okinawa Islands with respective rates of $+0.0162{ }^{\circ} \mathrm{C} /$ year and $+0.0124{ }^{\circ} \mathrm{C} /$ year (Table 2). Applying a linear regression, the decreasing trends of sclerosponge $\delta^{18} \mathrm{O}, \mathrm{Sr} / \mathrm{Ca}$, and $\mathrm{U} / \mathrm{Ca}$ from Miyako and Okinawa Islands are estimated respectively as $-3.62 \times 10^{-3}$ and $-3.81 \times 10^{-3}$ $\%$ o/year, $-1.55 \times 10^{-3}$ and $-1.18 \times 10^{-3} \mathrm{mmol} / \mathrm{mol} /{ }^{\circ} \mathrm{C} /$ year, and $-0.271 \times 10^{-3}$ and $-0.727 \times 10^{-3} \mu \mathrm{mol} / \mathrm{mol} /$ ${ }^{\circ} \mathrm{C} /$ year (Table 2). The $\delta^{18} \mathrm{O}$ values of biogenic carbonates are well known to reflect the temperature and $\delta^{18} \mathrm{O}$
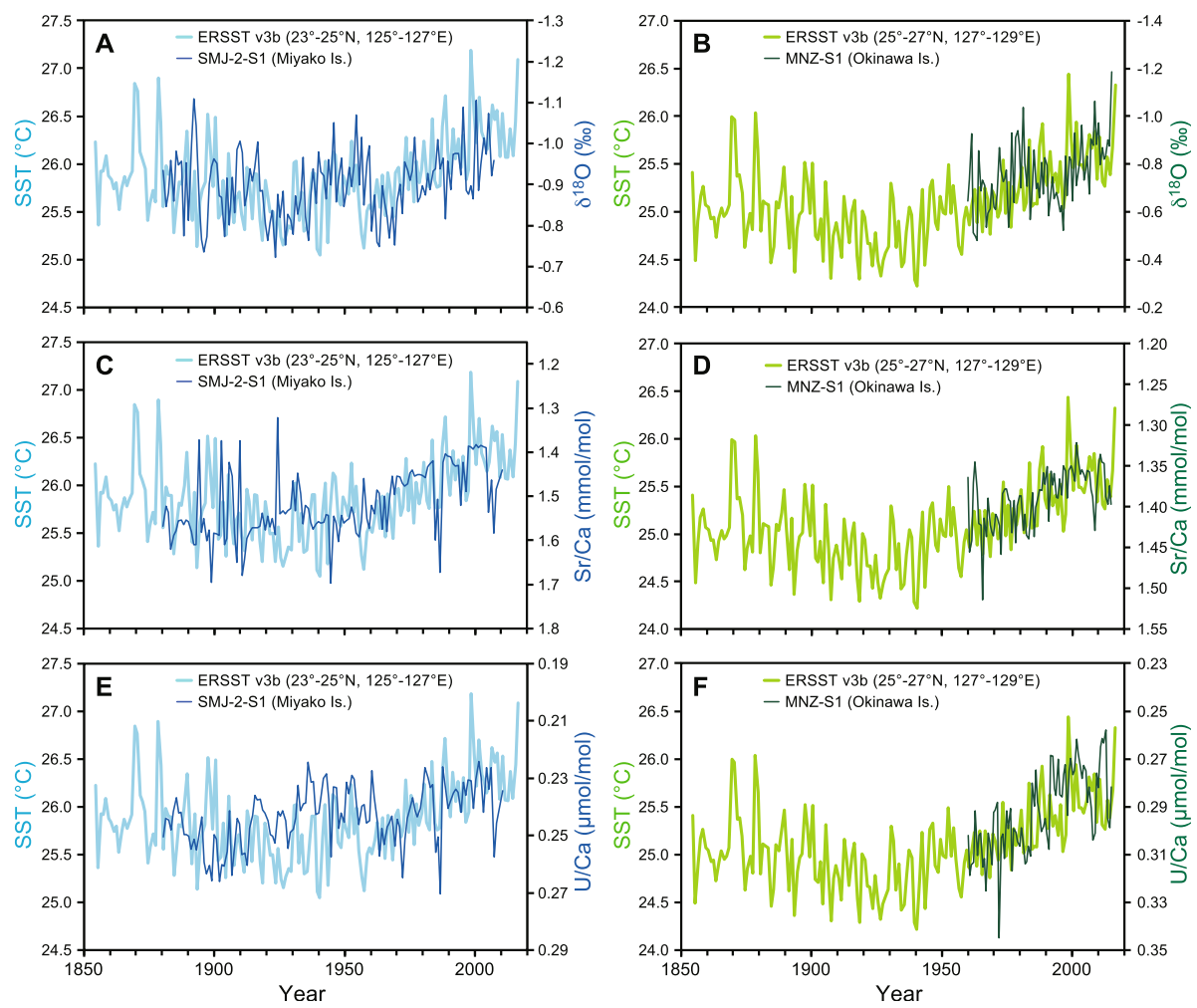

Fig. 7 Comparison of time series of sclerosponge $\delta^{18} \mathrm{O}(\mathbf{A}$ and $\mathbf{B}), \mathrm{Sr} / \mathrm{Ca}(\mathbf{C}$ and $\mathbf{D})$, and U/Ca (E and F) from Miyako Island (left panels) and Okinawa Island (right panels) with instrumental SST for 1880-2016 (ERSST v3b, http://iridl.Ideo.columbia.edu/) 
Table 2 Post-1960 trends estimated from SST and sclerosponge $\delta^{18} \mathrm{O}$, Sr/Ca, U/Ca records

\begin{tabular}{|c|c|c|c|c|c|c|c|c|}
\hline ID & Locality & SST $\left({ }^{\circ} \mathrm{C} /\right.$ year $)$ & $\begin{array}{l}\delta^{18} 0 \text { slope } \\
\text { (\%o/year) }\end{array}$ & $\begin{array}{l}\text { Dependence } \\
\left(\% \circ /{ }^{\circ} \mathrm{C}\right)\end{array}$ & $\begin{array}{l}\mathrm{Sr} / \mathrm{Ca} \text { slope } \\
\text { (mmol/mol/year) }\end{array}$ & $\begin{array}{l}\text { Dependence } \\
\left(\mathrm{mmol} / \mathrm{mol} /{ }^{\circ} \mathrm{C}\right)\end{array}$ & $\begin{array}{l}\text { U/Ca slope } \\
\text { ( } \mu \mathrm{mol} / \mathrm{mol} / \text { year) }\end{array}$ & $\begin{array}{l}\text { Dependence } \\
\left(\mu \mathrm{mol} / \mathrm{mol} /{ }^{\circ} \mathrm{C}\right)\end{array}$ \\
\hline \multirow[t]{2}{*}{ MNZ-S1 } & Okinawa Is. & +0.0124 & -0.00381 & -0.307 & -0.00118 & -0.095 & -0.000727 & -0.059 \\
\hline & & $R=0.605$ & $R=-0.444$ & & $R=-0.551$ & & $R=-0.683$ & \\
\hline \multirow[t]{2}{*}{ SMJ-2-S1 } & Miyako Is. & +0.0162 & -0.00362 & -0.223 & -0.00155 & -0.096 & -0.000271 & -0.017 \\
\hline & & $R=0.672$ & $R=-0.622$ & & $R=-0.360$ & & $R=-0.380$ & \\
\hline
\end{tabular}

The $R$ value for the linear regression between age and variable (SST, $\delta^{18} \mathrm{O}, \mathrm{Sr} / \mathrm{Ca}$, and $\mathrm{U} / \mathrm{Ca}$ ) is statistically significant at the $95 \%$ confidence limits

of seawater, the evidence of which was also confirmed for the species $A$. wellsi sclerosponge (Grottoli et al. 2010). The SST dependence of SMJ-2-S1 $\delta^{18} \mathrm{O}$ is almost identical to those of the same species from Saipan (ca. $-0.24 \% /{ }^{\circ} \mathrm{C}$ ) (Grottoli et al. 2010) and of inorganic calcite (ca. $\left.-0.22 \% /{ }^{\circ} \mathrm{C}\right) \quad\left(\mathrm{Kim}\right.$ and $\left.\mathrm{O}^{\prime} \mathrm{Neil} 1997\right)$. The value $\left(-0.307 \% /{ }^{\circ} \mathrm{C}\right)$ of $\mathrm{MNZ}-\mathrm{S} 1 \delta^{18} \mathrm{O}$ is much higher than expected; implying that seawater $\delta^{18} \mathrm{O}$ at the sclerosponge living site in Okinawa has decreased by approximately $0.1 \%$ since 1960 . Although the SST dependencies of Sr/ $\mathrm{Ca}$ for the long-term trend are almost identical between the two sclerosponge samples, several abrupt excursions in the $\mathrm{Sr} / \mathrm{Ca}$ signals did not track SST variations (Fig. 7). For A. wellsi, such inconsistency between $\mathrm{Sr} / \mathrm{Ca}$ and SST is explainable by an ICP-MS interference with accurate $\mathrm{Sr} / \mathrm{Ca}$ measurement of high-Mg materials and by the interference of $\mathrm{Mg}$ with $\mathrm{Sr}$ incorporation into the highMg calcite (Morse and Bender 1990; Grottoli et al. 2010). For $\mathrm{U} / \mathrm{Ca}$, the mechanisms of uranyl complexes incorporation into carbonates are very complicated (Langmuir 1978; DeCarlo et al. 2015). The post-1960 decreasing trend and SST dependency for U/Ca are largely different between the two samples (Table 2). Furthermore, the $\mathrm{U} / \mathrm{Ca}$ and $\mathrm{Sr} / \mathrm{Ca}$ values correlated with moderately positive $r$ values of 0.66 for SMJ-2-S1 and 0.67 for MNZ-S1, but no significant correlations were found with $\delta^{18} \mathrm{O}$ values (Table 3). Considering results of earlier reports (Grottoli 2006; Grottoli et al. 2010; Wu and Grottoli 2010), one can infer that the high-Mg calcite $\mathrm{Sr} / \mathrm{Ca}$ and $\mathrm{U} / \mathrm{Ca}$ values of $A$. wellsi sclerosponges might not be a useful indicator for temperature, unlike those of aragonite sclerosponges (Astrosclera willeyana and Ceratoporella nicholsoni) (Rosenheim et al. 2004; Fallon et al. 2005; Haase-Schramm et al. 2005; Waite et al. 2018; Asami et al. 2020a).

Unlike the $\mathrm{Sr} / \mathrm{Ca}$ and $\mathrm{U} / \mathrm{Ca}$ records, the $\delta^{18} \mathrm{O}$ time series of the SMJ-2-S1 sample clearly showed decadescale variation for 1880-2012 (Fig. 7). Spectral analyses of the 5-year moving average time series using a multitaper method (see the methodology and climatic applications in earlier studies (Mann and Lees 1996; Ghil et al. 2002; Asami et al. 2020b)) revealed a marked concentration of its variance in periodicity of approximately 2,3 , $6.5,7-10$, and 20-30 years/cycle for 1880-2012, which exceed the 90\% confidence level (Fig. 8A). The similar periodicity roughly corresponds to the significant spectra of instrumental SST in Miyako Island for 1880-2012 (Fig. 8B). These results indicate that the sea surface condition around Miyako Island had been highly dominated by interannual and decadal variations in temperature and seawater $\delta^{18} \mathrm{O}$ since the late nineteenth century. It is conceivable that the interannual variations with

Table 3 Correlations between sclerosponge geochemical records ${ }^{a}$

\begin{tabular}{|c|c|c|c|c|c|}
\hline & $\delta^{18} \mathrm{O}$ & $\mathrm{Sr} / \mathrm{Ca}$ & $\mathrm{Ba} / \mathrm{Ca}$ & $\mathrm{Pb} / \mathrm{Ca}$ & $\mathrm{U} / \mathrm{Ca}$ \\
\hline \multicolumn{6}{|c|}{ MNZ-S1 (Okinawa) 1960-2015 } \\
\hline$\delta^{13} \mathrm{C}$ & 0.51 & 0.55 & 0.06 & -0.78 & 0.69 \\
\hline$\delta^{18} \mathrm{O}$ & & -0.08 & -0.19 & -0.32 & 0.09 \\
\hline $\mathrm{Sr} / \mathrm{Ca}$ & & & 0.48 & -0.59 & 0.67 \\
\hline $\mathrm{Ba} / \mathrm{Ca}$ & & & & -0.27 & 0.18 \\
\hline $\mathrm{Pb} / \mathrm{Ca}$ & & & & & -0.58 \\
\hline \multicolumn{6}{|c|}{ SMJ-2-S1 (Miyako) 1960-2012 } \\
\hline$\delta^{13} \mathrm{C}$ & 0.63 & 0.31 & -0.41 & -0.64 & 0.36 \\
\hline$\delta^{18} \mathrm{O}$ & & 0.19 & -0.08 & -0.24 & 0.26 \\
\hline $\mathrm{Sr} / \mathrm{Ca}$ & & & 0.24 & -0.30 & 0.66 \\
\hline $\mathrm{Ba} / \mathrm{Ca}$ & & & & 0.37 & 0.15 \\
\hline $\mathrm{Pb} / \mathrm{Ca}$ & & & & & -0.25 \\
\hline
\end{tabular}

${ }^{a}$ Coefficent values in italics and bold fall outside $(p>0.01)$ and inside $(p<0.01)$ the $99 \%$ confidence intervals, respectively 

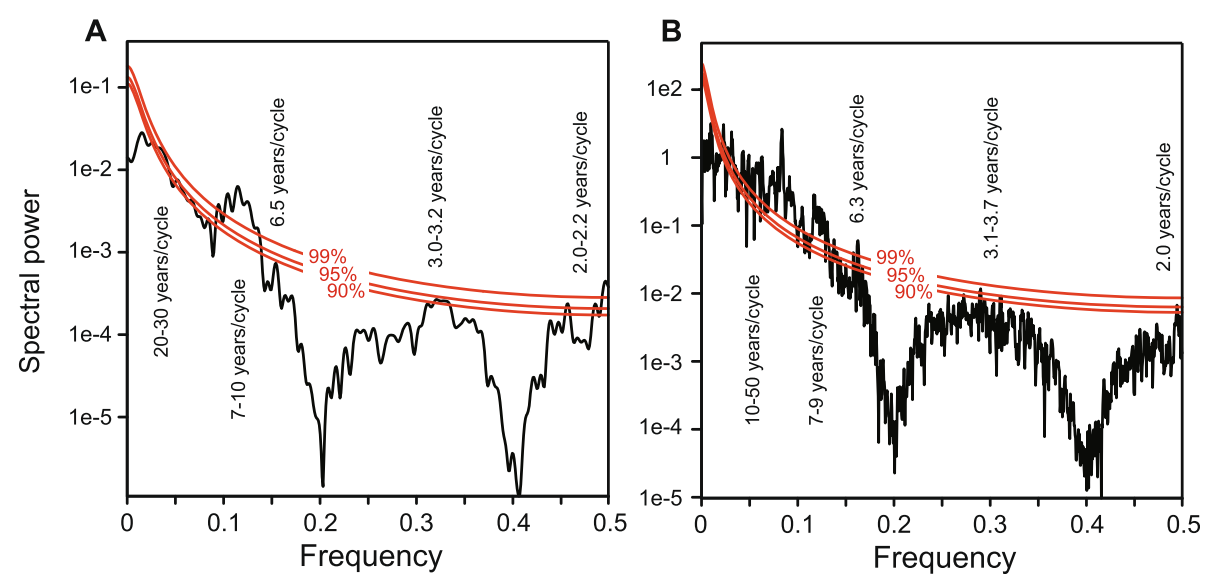

Fig. 8 Results of multi-taper method spectral analyses of the SMJ-2-S1 sclerosponge $\delta^{18} \mathrm{O}(\mathbf{A})$ and instrumental SST (ERSST V3b) (B) for 18802012. The $90 \%, 95 \%$, and $99 \%$ confidence levels are shown as red lines. Numbers denote interannual to decadal periodicity with significant peaks at the confidence level

relatively shorter and longer periodicity of about 2 years and 3-8 years are linked respectively to the East Asian Monsoon and El Niño/Southern Oscillation, which is consistent with climatic signatures in coral $\delta^{18} \mathrm{O}$ records from the Ryukyu Islands (Mishima et al. 2010; Asami et al. 2020b). The Pacific Decadal Oscillation (PDO), a dominant climate mode in the Pacific Ocean, was found to be significant based on modern long-coral $\delta^{18} \mathrm{O}$ records kept for the northwestern tropical-to-temperate Pacific region for the last two centuries (Asami et al. 2005; Watanabe et al. 2014). Therefore, it is likely that the decadal-scale variations with the periodicity of 20
30 years detected in the sclerosponge $\delta^{18} \mathrm{O}$ record might be associated with the PDO variations.

\subsection{Other environmental signals: $\mathrm{Ba} / \mathrm{Ca}$ and $\mathrm{Pb} / \mathrm{Ca}$}

The $\mathrm{Ba} / \mathrm{Ca}$ values of the SMJ-2-S1 and MNZ-S1 samples were $0.19-10.3 \mu \mathrm{mol} / \mathrm{mol}$ for $1880-2012$ and $0.00-2.80$ $\mu \mathrm{mol} / \mathrm{mol}$ for 1960-2015 (Fig. 9). Considering the within-skeleton $\mathrm{Ba} / \mathrm{Ca}$ variations of $\pm 0.54 \mu \mathrm{mol} / \mathrm{mol}$ (RSD, $7.7 \%$ ) for SMJ-2-S1 and $\pm 0.17 \mu \mathrm{mol} / \mathrm{mol}$ for MNZ-S1 (RSD, 9.9\%) (Fig. 4), the $\mathrm{Ba} / \mathrm{Ca}$ values and temporal variations differ greatly between the two samples and also from a different species $C$. nicholsoni from the

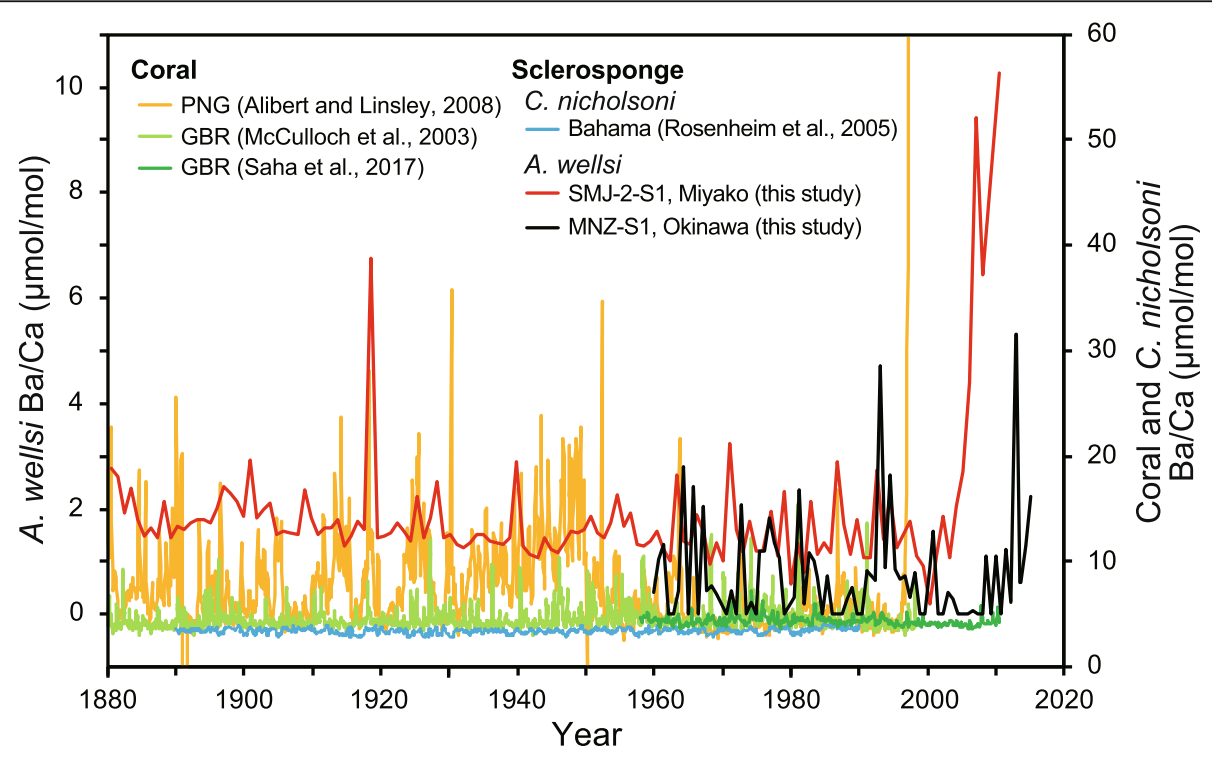

Fig. 9 Secular $\mathrm{Ba} / \mathrm{Ca}$ variations in sclerosponges and corals from the Pacific and Atlantic Oceans 
Atlantic (Rosenheim et al. 2005b). These can be partially attributable to wide interspecific, intraspecific, and within-skeleton variations in $\mathrm{Ba} / \mathrm{Ca}$, as reported from an earlier study (Asami et al. 2020a) and as portrayed in Fig. 4. Another reason for the different $\mathrm{Ba} / \mathrm{Ca}$ variations might be related to local environmental effects. Earlier studies of annually banded corals in the Pacific Ocean demonstrated that increasing short-term signals in coral $\mathrm{Ba} / \mathrm{Ca}$ time series generally corresponded to river discharge and terrestrial runoff associated with heavy rainfall and land-use practices (McCulloch et al. 2003; Saha et al. 2018) and to ocean currents (Alibert and Kinsley 2008a, 2008b) (Fig. 9). It is noteworthy that the SMJ-2$\mathrm{S} 1 \mathrm{Ba} / \mathrm{Ca}$ values have increased markedly since 2000: its signature is not found in the MNZ-S1 values. That large difference cannot be explained by regional differences in precipitation and ocean currents because the two sites are located in almost identical climate settings (Fig. 1). One possibility for the abrupt $\mathrm{Ba} / \mathrm{Ca}$ increase in the SMI-2-S1 record would be related to a land-use change: large-scale roads had been constructed from the late 1990 s to the early 2010s, and resort facilities with hot spring, golf course, and hotel had developed from the 1990s to the 2010s around the study site in the southern part of Miyako Island (Geospatial Information Authority of Japan, https://mapps.gsi.go.jp/) (Supplementary Figure S2). Some earlier studies demonstrated that skeletal Ba/ $\mathrm{Ca}$ ratios of coral aragonite can be a proxy for the amount of land-based sediment input to the reef environment because $\mathrm{Ba}$ is sourced from the fine-grained components of terrestrial soils (McCulloch et al. 2003; Fleitmann et al. 2007; Prouty et al. 2010). It is, therefore, likely that the temporal $\mathrm{Ba} / \mathrm{Ca}$ variations in our sclerosponge SMJ-2-S1 sample might have recorded the history of terrigenous sediment flux associated with land development since 1880 . Nevertheless, we cannot clarify the reason from the present study results because the physiological process and the mode of barium incorporation into the sclerosponge skeleton remain unknown (Rosenheim et al. 2005b; Allison et al. 2012; Asami et al. 2020a).

The $\mathrm{Pb} / \mathrm{Ca}$ values of the SMJ-2-S1 and MNZ-S1 samples were $228-3349 \mathrm{nmol} / \mathrm{mol}$ for $1880-2012$ and 1699-4146 nmol/mol for 1960-2015 (Fig. 10). These $\mathrm{Pb}$ concentrations are much higher than those of corals: a fact which agrees with results described in earlier reports (Benavides and Druffel 1986; Shen and Boyle 1987). The relatively high $\mathrm{Pb} / \mathrm{Ca}$ records are attributable to a biological characteristic by which sclerosponges concentrate $\mathrm{Pb}$ in their skeleton by containing nutrition via filter feeding particulates with absorbed heavy-metal species (Hartman and Goreau 1966; Willenz and Hartman 1989). The temporal $\mathrm{Pb} / \mathrm{Ca}$ variations of our sclerosponges showed a similar increasing trend during the late twentieth century, but the values were significantly different (Fig. 10), considering the within-skeleton variations of $\pm 172 \mathrm{nmol} / \mathrm{mol}$ (RSD, 8.1\%) for SMJ-2-S1 and $\pm 253 \mathrm{nmol} / \mathrm{mol} \mathrm{(RSD,} \mathrm{7.8 \% )} \mathrm{for} \mathrm{MNZ-S1} \mathrm{(Fig.} \mathrm{4).}$ Moreover, our $\mathrm{Pb} / \mathrm{Ca}$ ratios of $A$. wellsi samples (high$\mathrm{Mg}$ calcite) are higher than that found from Kume Island (Ohmori et al. 2014), despite being close to our study site (Fig. 1), and are higher than those of C. nicholsoni (aragonite) (Lazareth et al. 2000; Rosenheim et al. 2005b). That difference indicates that the mechanisms of $\mathrm{Pb}$ incorporation might have large interspecific, intraspecific, and within-skeleton variations. Those indications can be partially supported by the results of an evaluation study of sclerosponge (Rosenheim et al. 2005b; Asami et al. 2020a) and our results portrayed in Fig. 4. An increasing trend was identifiable in our sclerosponge $\mathrm{Pb} /$ Ca records since 1950 (Fig. 10). The $\mathrm{Pb} / \mathrm{Ca}$ increase primarily accords with those of corals and sclerosponges

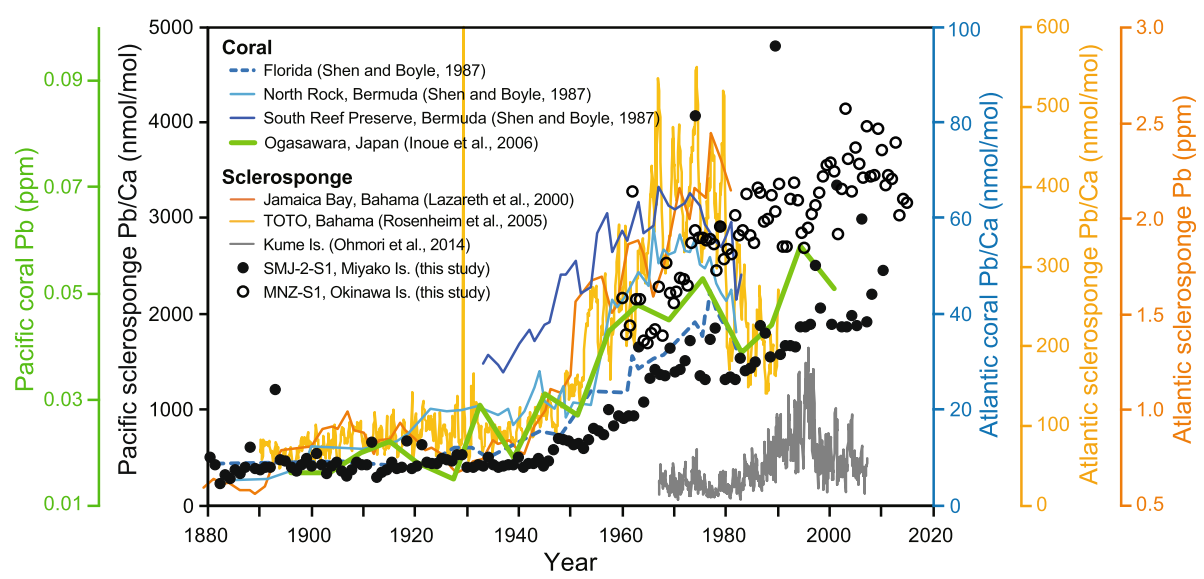

Fig. 10 Secular $\mathrm{Pb} / \mathrm{Ca}$ and $\mathrm{Pb}$ concentration variations in sclerosponges and corals from the Pacific and Atlantic Oceans 
from the Pacific and Atlantic oceans, which is attributed to $\mathrm{Pb}$ emission from industrial activities. The increases in the Atlantic coral and sclerosponge records were followed by a drop occurring in approximately the 1970s, caused by decreased use of lead alkyl additives in gasoline, mainly in the USA (Boutron et al. 1991; Rosman et al. 1993), but those in the Pacific records have been maintained since the 1950s (Inoue et al. 2006; this study). The anthropogenic $\mathrm{Pb} / \mathrm{Ca}$ signature found in our sclerosponge records is probably associated with industrial activities in eastern Asian countries and Chinese atmospheric aerosols (Zheng et al. 2004; Hao et al. 2008). The predominant source of $\mathrm{Pb}$ was identified by lead isotope ratios of the western Pacific corals (Inoue and Tanimizu 2008). The increasing $\mathrm{Pb} / \mathrm{Ca}$ trends of our sclerosponges from Miyako and Okinawa Islands accord well with the time series of $\mathrm{Pb}$ contents in an Ogasawara coral (Fig. 4), indicating that the continued increase of $\mathrm{Pb} / \mathrm{Ca}$ ratios after the 1980 s can be caused by a mixture of $\mathrm{Pb}$ emitted from Asian countries with heavy industrialization. However, the sclerosponge $\mathrm{Pb} / \mathrm{Ca}$ record from Kume Island (Ohmori et al. 2014) has maintained low until the 1980s and decreased since the late 1990s, the variation of which is not consistent with those of the Ogasawara coral and our sclerosponge records. One possible explanation of the difference is that the sclerosponges lived at different water depths of 2-10 m (this study) and $23 \mathrm{~m}$ (Ohmori et al. 2014). That is, it is likely that our sclerosponges and the Ogasawara coral, living in very shallow waters, may record the temporal variations in $\mathrm{Pb}$ concentration sensitively because aerosols with anthropogenically generated lead are transported to the sea surface through the atmosphere (Inoue and Tanimizu 2008). Further investigations of $\mathrm{Pb}$ isotope ratios $\left({ }^{206} \mathrm{~Pb} /{ }^{207} \mathrm{~Pb}\right.$ and $\left.{ }^{208} \mathrm{~Pb} /{ }^{207} \mathrm{~Pb}\right)$ must be conducted of our samples to clarify the potential source of $\mathrm{Pb}$ in the Miyako and Okinawa Islands.

\section{Conclusions}

From Acanthochaetetes wellsi sclerosponge samples for 1880-2012 and 1960-2015, collected respectively at Miyako Island and Okinawa Island in the Ryukyu Islands of southwestern Japan, we first generated near-annual resolved time series of skeletal $\delta^{13} \mathrm{C}, \delta^{18} \mathrm{O}$, and element/ $\mathrm{Ca}$ ratios $(\mathrm{Sr} / \mathrm{Ca}, \mathrm{Ba} / \mathrm{Ca}, \mathrm{Pb} / \mathrm{Ca}, \mathrm{U} / \mathrm{Ca})$. The $\delta^{13} \mathrm{C}$ values have decreased at an increasing rate since the midtwentieth century, indicating the anthropogenically derived Suess effect. Our estimations demonstrated that the $\delta^{13} \mathrm{C}$ decrease rate in the northwestern subtropical Pacific was similar to the Caribbean Sea before 1960 but about 1.4 times higher after 1960. The $\delta^{18} \mathrm{O}$ records were mostly accorded with long-term variations in seawater temperatures. Using spectral analysis, we detected significant periodicity of $2,3,6.5,7-10$, and $20-30$ year/ cycle in the $\delta^{18} \mathrm{O}$ time series, which indicates that sea surface conditions around the southern Ryukyu Islands had been dominated by interannual and decadal variations in temperature and seawater $\delta^{18} \mathrm{O}$ since the late nineteenth century.

In contrast to aragonite sclerosponges (A. willeyana and $C$. nicholsoni), the validity of $\mathrm{Sr} / \mathrm{Ca}$ and $\mathrm{U} / \mathrm{Ca}$ records of $A$. wellsi with high-Mg calcite skeleton for a robust proxy of seawater temperature cannot be determined from data used for this study. Compared to previously published data, the increasing $\mathrm{Pb} / \mathrm{Ca}$ trends after 1950 found in our sclerosponge records are probably caused by $\mathrm{Pb}$ emissions from industrial activities in eastern Asian countries and Chinese atmospheric aerosols. A great difference in the $\mathrm{Ba} / \mathrm{Ca}$ variations is apparent between our two sclerosponges, which might be related to local environments. However, large intraspecific and within-skeleton variations in $\mathrm{Ba} / \mathrm{Ca}$ and $\mathrm{Pb} / \mathrm{Ca}$ prevent the interpretation of environmental signals recorded in the sclerosponge samples. This study suggests that, with more high-resolution age determinations, sclerospongebased reconstruction studies can elucidate secular variations in ocean environments on seasonal, annual, and interannual time scales.

The Kuroshio Current allows the development of widely distributed reefs with a highly diversified biota of the Ryukyu Islands during the late Quaternary (Iryu et al. 2006). In combination with the geochemistry of calcified marine organisms such as corals and giant clams, if long-lived sclerosponges are collected from deeper ocean environments, we can generate long time series reflecting spatial and vertical changes in coral reef environments of the Ryukyu Islands that have taken place over the past few hundred years, extending far beyond the limits of meteorological observation data, and over the last deglaciation.

\section{Abbreviations}

JODC: Japan Oceanographic Data Center; VPDB: Vienna Standard Pee Dee Belemnite

\section{Supplementary Information}

The online version contains supplementary material available at https://doi. org/10.1186/s40645-021-00434-7.

\footnotetext{
Additional file 1: Table S1. Radiocarbon data reported as $\Delta 14 \mathrm{C}$ of the sample series extracted from the sclerosponge SMJ-2-S1 with the estimated date of skeletal formation. Figure S1. Comparison of the depth domain $\delta^{13} \mathrm{C}$ profile of the sclerosponge MNZ-S1 with the $\delta^{13} \mathrm{C}$ time series of SMJ-2-S1 determined by radiocarbon data. The decreasing trend of MNZ-S1 $\delta^{13} \mathrm{C}$ record under the condition that the skeletal growth rate is $1.42 \mathrm{~mm}$ /year shows good agreement with that of SMJ-2-S1 for 1960 2012, yielding a high correlation between the two regression lines ( $r=$ 0.99). Figure S2. Aerial photos of the southern part of Miyako Island in 1995 and 2019 (modified from Geospatial Information Authority of Japan, https://mapps.gsi.go.jp/), showing the locations of the sclerosponge sampling site and large-scale road and resort constructions.
} 


\section{Acknowledgements}

We are grateful to an editor (Dr. Y. Okazaki) and two anonymous reviewers for their helpful and valuable suggestions on the manuscript. We also thank S. Ishikawa, M. Chinen, and Y. Akamine (University of the Ryukyus) for help with experiments.

\section{Authors' contributions}

RA designed the study, analyzed the samples and data, and wrote the manuscript. YM, MM, and TS carried out the fieldwork and sampling. TM, RS, $\mathrm{RU}$, and $\mathrm{YI}$ collaborated with RA in the experimental study. The authors read and approved the final manuscript.

\section{Funding}

This research was supported by the Japan Society for the Promotion of Science KAKENHI (Grant-in-Aid for Scientific Research) Grant numbers 26550012, 26707028, and 18K18522 to RA and $15 \mathrm{H} 01729$ to RU, and the NEXT Program Grant Number GR083 to TS.

\section{Availability of data and materials}

Sclerosponge data generated in this study will be available at NOAA NCDC World Data Center for Paleoclimatology (https://www.ncdc.noaa.gov/dataaccess/paleoclimatology-data). Please contact the corresponding author for data requests.

\section{Declarations}

\section{Competing interests}

The authors declare that they have no competing interests.

\section{Author details}

Institute of Geology and Paleontology, Graduate School of Science, Tohoku University, 6-3, Aramaki-Aza-Aoba, Sendai 980-8578, Japan. ${ }^{2}$ Department of Physics and Earth Sciences, Faculty of Science, University of the Ryukyus, 1 Senbaru, Nishihara, Okinawa 903-0213, Japan. ${ }^{3}$ Department of Earth and Environmental Sciences, Graduate School of Environmental Studies, Nagoya University, Furo-cho, Chikusa-ku, Nagoya 464-8601, Japan. ${ }^{4}$ Trans-disciplinary Research Organization for Subtropical Island Studies, University of the Ryukyus, 1 Senbaru, Nishihara, Okinawa 903-0213, Japan. ${ }^{5}$ Graduate School of Engineering and Science, University of the Ryukyus, 1 Senbaru, Nishihara, Okinawa 903-0213, Japan. ${ }^{6}$ Tropical Biosphere Research Center, Sesoko Station, University of the Ryukyus, 3422 Sesoko, Motobu, Okinawa 905-0227, Japan. 'Department of Civil and Environmental Engineering, Graduate School of Engineering, Tohoku University, 6-6-06 Aramaki-Aza-Aoba, Sendai 980-8579, Japan.

\section{Received: 10 November 2020 Accepted: 8 June 2021}

\section{Published online: 28 June 2021}

\section{References}

Abe O, Agata S, Morimoto M, Abe M, Yoshimura K, Hiyama T, Yoshida N (2009) A 6.5-year continuous record of sea surface salinity and seawater isotopic composition at Harbour of Ishigaki Island, southwest Japan. Isot Environ Health Stud 45(3):247-258. https://doi.org/10.1080/10256010903083847

Abram NJ, HV MG, Tierney JE, Evans MN, NP MK, Kaufman DS, the PAGES 2k Consortium (2016) Early onset of industrial-era warming across the oceans and continents. Nature 536(7617):411-418. https://doi.org/10.1038/nature1 9082

Alibert C, Kinsley L (2008a) A 170-year Sr/Ca and Ba/Ca coral record from the western Pacific warm pool: 1. What can we learn from an unusual coral record? J Geophys Res 113(C4):C04008. https://doi.org/10.1029/2006JC003979

Alibert C, Kinsley L (2008b) A 170-year Sr/Ca and Ba/Ca coral record from the western Pacific warm pool: 2. A window into variability of the New Ireland Coastal Undercurrent. J Geophys Res 113(C6):C06006. https://doi.org/10.102 9/2007JC004263

Allison N, Tudhope AW, EIMF (2012) The skeletal geochemistry of the sclerosponge Astrosclera willeyana: implications for biomineralisation processes and paleoenvironmental reconstruction. Palaeogeogr Palaeoclimatol Palaeoecol 313-314:70-77. https://doi.org/10.1016/.palaeo.2 011.10 .009

Asami R, Felis T, Deschamps P. Hanawa K, Iryu Y, Bard E, Durand N, Murayama M (2009) Evidence for tropical South Pacific climate change during the Younger
Dryas and the Bølling-Allerød from geochemical records of fossil Tahiti corals. Earth Planet Sci Lett 288(1-2):96-107. https://doi.org/10.1016/j.epsl.2 009.09.011

Asami R, Kinjo A, Ohshiro D, Naruse T, Mizuyama M, Uemura R, Shinjo R, Ise Y, Fujita Y, Sakamaki T (2020a) Evaluation of geochemical records as a paleoenvironmental proxy in the hypercalcified demosponge Astrosclera willeyana. Prog Earth Planet Sci 7(1):15. https://doi.org/10.1186/s40645-02000329-z

Asami R, Konishi M, Tanaka K, Uemura R, Furukawa M, Shinjo R (2015) Late Holocene coral reef environment recorded in Tridacnidae shells from archaeological sites in Okinawa-jima, subtropical southwestern Japan. Island Arc 24(1):61-72. https://doi.org/10.1111/iar.12076

Asami R, Yamada T, Iryu Y, Quinn TM, Meyer CP, Paulay G (2005) Interannual and decadal variability of the western Pacific sea surface condition for the years 1787-2000: reconstruction based on stable isotope record from a Guam coral. J Geophys Res 110(C5):C05018. https://doi.org/10.1029/2004JC002555

Asami R, Yoshimura N, Toriyabe H, Minei S, Shinjo R, Hongo C, Sakamaki T, Fujita K (2020b) High-resolution evidence for middle Holocene East Asian winter and summer monsoon variations: snapshots of fossil coral records. Geophys Res Lett 47:e2020GL088509 https://doi.org/10.1029/2020GL088509

Benavides LM, Druffel ERM (1986) Sclerosponge growth rate as determined by ${ }^{210} \mathrm{Pd}$ and $\Delta^{14} \mathrm{C}$ chronologies. Coral Reefs 4(4):221-224. https://doi.org/10.1 007/BF00298080

Böhm F, Haase-Schramm A, Eisenhauer A, Dullo W-C, Joachimski MM, Lehnert H, Reitner J (2002) Evidence for preindustrial variations in the marine surface water carbonate system from coralline sponges. Geochem Geophys Geosyst 3(3):1019-1013. https://doi.org/10.1029/2001GC000264

Böhm F, Joachimski MM, Dullo W-C, Eisenhauer A, Lehnert H, Reitner J, Wörheide $G$ (2000) Oxygen isotope fractionation in marine aragonite of coralline sponges. Geochim Cosmochim Acta 64(10):1695-1703. https://doi.org/10.101 6/50016-7037(99)00408-1

Böhm F, Joachimski MM, Lehnert H, Morgenroth G, Kretschmer W, Vacelet J, Dullo W-C (1996) Carbon isotope records from extant Caribbean and South Pacific sponges: evolution of $\delta^{13} \mathrm{C}$ in surface water DIC. Earth Planet Sci Lett 139(1-2):291-303. https://doi.org/10.1016/0012-821X(96)00006-4

Boutron CF, Görlach U, Candelone J-P, Bolshov MA, Delmas RJ (1991) Decrease in anthropogenic lead, cadmium and zinc in Greenland snows since the late 1960s. Nature 353(6340):153-1156. https://doi.org/10.1038/353153a0

DeCarlo TM, Gaetani GA, Holcomb M, Cohen AL (2015) Experimental determination of factors controlling $\mathrm{U} / \mathrm{Ca}$ of aragonite precipitated from seawater: implications for interpreting coral skeleton. Geochim Cosmochim Acta 162:151-165 https://doi.org/10.1016/.gca.2015.04.016

Druffel ERM, Benavides LM (1986) Input of excess $\mathrm{CO}_{2}$ to the surface ocean based on ${ }^{13} \mathrm{C} /{ }^{12} \mathrm{C}$ ratios in a banded Jamaican sclerosponge. Nature 321(6065):58-61. https://doi.org/10.1038/321058a0

Fallon SJ, Guilderson TP, Caldeira K (2003) Carbon isotope constraints on vertical mixing and air-sea $\mathrm{CO}_{2}$ exchange. Geophys Res Lett 30(24):2289. https://doi. org/10.1029/2003GL018049

Fallon SJ, McCulloch MT, Guilderson TP (2005) Interpreting environmental signals from the coralline sponge Astrosclera willeyana. Palaeogeogr Palaeoclimatol Palaeoecol 228(1-2):58-69. https://doi.org/10.1016/.jpalaeo.2005.03.053

Fleitmann D, Dunbar RB, McCulloch M, Mudelsee M, Vuille M, McClanahan TR, Cole JE, Eggins S (2007) East African soil erosion recorded in a 300 year old coral colony from Kenya. Geophys Res Lett 34(4):L04401. https://doi.org/10.1 029/2006GL028525

Gilis M, Grauby O, Willenz P, Dubois P, Heresanu V, Baronnet A (2013) Biomineralization in living hypercalcified demosponges: toward a shared mechanism? J Struct Biol 183(3):441-454. https://doi.org/10.1016/j.jsb.2 013.05 .018

Grottoli AG (2006) Monthly resolved stable oxygen isotope record in a Palauan sclerosponge Acanthocheatetes wellsi for the period of 1977-2001. Proc 10th Int Coral Reef Symp 2004:572-579

Grottoli AG, Adkins JF, Panero WR, Reaman DM, Moots K (2010) Growth rates, stable oxygen isotopes $\left(\delta^{18} \mathrm{O}\right)$, and strontium $(\mathrm{Sr} / \mathrm{Ca}$ ) composition in two species of Pacific sclerosponges (Acanthocheatetes wellsi and Astrosclera willeyana) with $\delta^{18} \mathrm{O}$ calibration and application to paleoceanography. J Geophys Res 115(C6):C06008. https://doi.org/10.1029/2009JC005586

Ghil M, Allen MR, Dettinger MD, Ide K, Kondra-shov D, Mann ME, Robertson AW, Saunders A, Tian Y, Varadi F, Yiou P (2002) Advanced spectral methods for climatic time series. Rev Geophys 40:1003. https://doi.org/10.1029/2 000RG000092 
Haase-Schramm A, Böhm F, Eisenhauer A, Garbe-Schönberg D, Dullo W-C, Reitner $J$ (2005) Annual to interannual temperature variability in the Caribbean during the Maunder sunspot minimum. Paleoceanography 20(4):PA4015. https://doi.org/10.1029/2005PA001137

Hao YC, Guo ZG, Yang ZS, Fan DJ, Fang M, Li XD (2008) Tracking historical lead pollution in the coastal area adjacent to the Yangtze River Estuary using lead isotopic compositions. Environ Pollut 156(3):1325-1331. https://doi.org/10.10 6/j.envpol.2008.02.023

Hartman WD (1980) Ecology of Recent sclerosponges. In: Hartman WD, Wendt JW, Wiedenmayer F (eds) Living and fossil sponges. Sedimenta, Miami, pp 253-255

Hartman WD, Goreau TF (1966) Ceratoporella, a living sponge with stromatoporoid affinities. Am Zool 6:563-564

Hartman WD, Goreau TF (1975) A Pacific tabulate sponge, living representative of a new order of sclerosponges. Postilla 167:1-21. https://doi.org/10.5962/bhl. part.6459

Hathorne EC, Gagnon A, Felis T, Adkins J, Asami R, Boer W, Caillon N, Case D, Cobb KM, Douville E, deMenocal P, Eisenhauer A, Garbe-Schönberg D, Geibert W, Goldstein S, Hughen K, Inoue M, Kawahata H, Kölling M, Cornec FL, Linsley BK, McGregor HV, Montagna P, Nurhati IS, Quinn TM, Raddatz J, Rebaubier H, Robinson L, Sadekov A, Sherrell R, Sinclair D, Tudhope AW, Wei G, Wong H, Wu HC, You CF (2013) Interlaboratory study for coral Sr/Ca and other element/Ca ratio measurements. Geochem Geophys Geosyst 14(9): 3730-3750. https://doi.org/10.1002/ggge.20230

Hirabayashi S, Yokoyama Y, Suzuki A, Miyairi Y, Aze T (2017) Multidecadal oceanographic changes in the western Pacific detected through highresolution bomb-derived radiocarbon measurements on corals. Geochem Geophys Geosyst 18(4):1608-1617. https://doi.org/10.1002/2017GC006854

Inoue M, Hata A, Suzuki A, Nohara M, Shikazono N, Yim WW, Hantoro WS, Donghuai S, Kawahata H (2006) Distribution and temporal changes of lead in the surface seawater in the western Pacific and adjacent seas derived from coral skeletons. Environ Pollut 144(3):1045-1052. https://doi.org/10.1016/j. envpol.2005.11.048

Inoue M, Tanimizu M (2008) Anthropogenic lead inputs to the western Pacific during the 20th century. Sci Total Environ 406(1-2):123-130. https://doi.org/1 0.1016/j.scitotenv.2008.07.032

Iryu Y, Matsuda H, Machiyama H, Piller WE, Quinn TM, Mutti M (2006) Introductory perspective on the COREF Project. Island Arc 15(4):393-406. https://doi.org/10.1111/j.1440-1738.2006.00537.x

Keeling CD, Mook WG, Tans PP (1979) Recent trends in the ${ }^{13} \mathrm{C} /{ }^{12} \mathrm{C}$ ratio of atmospheric carbon dioxide. Nature 277(5692):121-123. https://doi.org/10.1 038/277121a0

Kim S-T, O'Neil JR (1997) Equilibrium and nonequilibrium oxygen isotope effects in synthetic carbonates. Geochim Cosmochim Acta 61(16):3461-3475. https://doi.org/10.1016/S0016-7037(97)00169-5

Langmuir D (1978) Uranium solution-mineral equilibria at low temperatures with applications to sedimentary one deposits. Geochim Cosmochim Acta 42(6): 547-569. https://doi.org/10.1016/0016-7037(78)90001-7

Lazareth C, Willenz P, Navez J, Keppens E, Dehairs F, Andre L (2000) Sclerosponges as a new potential recorder of environmental changes: lead in Ceratoporella nicholsoni. Geology 28(6):515-518. https://doi.org/10.1130/ 0091-7613(2000)28515:SAANPR2.0.CO;2

Mann ME, Lees JM (1996) Robust estimation of background-noise and signaldetection in climatic time-series. Clim Change 33:409-445. https://doi.org/1 $0.1007 /$ BF00142586

McCulloch M, Fallon S, Wyndham T, Hendy E, Lough J, Barnes D (2003) Coral record of increased sediment flux to the inner Great Barrier Reef since European settlement. Nature 421(6924):727-730. https://doi.org/10.1038/na ture01361

Mishima M, Suzuki A, Nagao M, Ishimura T, Inoue M, Kawahata H (2010) Abrupt shift toward cooler condition in the earliest 20th century detected in a 165 year coral record from Ishigaki Island, southwestern Japan. Geophys Res Lett 37(15):L15609. https://doi.org/10.1029/2010GL043451

Moore MD, Charles CD, Rubenstone JL, Fairbanks RG (2000) U/Th-dated sclerosponges from the Indonesian Seaway record subsurface adjustments to west Pacific winds. Paleoceanography 15(4):404-416. https://doi.org/10.102 9/1999PA000396

Morse JW, Bender ML (1990) Partition-coefficients in calcite: examination of factors influencing the validity of experimental results and their application to natural systems. Chem Geol 82(3-4):265-277. https://doi.org/10.1016/ 0009-2541(90)90085-L
Ohmori K, Watanabe T, Tanimizu M, Shirai K (2014) Lead concentration and isotopic composition in the Pacific sclerosponge (Acanthochaetetes wellsi) reflects environmental lead pollution. Geology 42(4):287-290. https://doi. org/10.1130/G34316.1

Okai T, Suzuki A, Kawahata H, Terashima S, Imai N (2002) Preparation of a new Geological Survey of Japan geochemical reference material: coral JCp-1. Geostand Newslett 26(1):95-99. https://doi.org/10.1111/j.1751-908X.2002. tb00627.x

PAGES 2k Consortium (2013) Continental-scale temperature variability during the past two millennia. Nat Geosci 6(5):339-346. https://doi.org/10.1038/ngeo1797

Prouty NG, Field ME, Stock JD, Jupiter SD, McCulloch M (2010) Coral Ba/Ca records of sediment input to the fringing reef of the southshore of Moloka'i, Hawai'i over the last several decades. Mar Pollut Bull 60(10):1822-1835. https://doi.org/10.1016/j.marpolbul.2010.05.024

Quay PD, Tilbrook B, Wong CS (1992) Oceanic uptake of fossil fuel $\mathrm{CO}_{2}$ : carbon13 evidence. Science 256(5053):74-79. https://doi.org/10.1126/science.256. 5053.74

Reitner J (1992) "Coralline Spongien". Der Versuch einer phylogenetischtaxonomischen Analyse. Coralline sponges an attempt of a phylogenetictaxonomic analysis. Berliner Geowiss Abh, Reihe E Palaeobiol 1:1-352

Reitner J, Engeser TS (1987) Skeletal structures and habitats of recent and fossil Acanthochaetetes (subclass Tetractinomorpha, Demospongiae, Porifera). Coral Reefs 6(1):13-18. https://doi.org/10.1007/BF00302207

Reitner J, Gautret P (1996) Skeletal formation in the modern but ultraconservative chaetetid sponge Spirastrella (Acanthochaetetes) wellsi (Demospongiae, Porifera). Facies 34(1):193-208. https://doi.org/10.1007/BF02546164

Reitner J, Wörheide G, Lange R, Thiel V (1997) Biomineralization of calcified skeletons in three Pacific coralline demosponges- an approach to the evolution of basal skeletons. Cour Forsch Inst Senckenberg 201:371-383 https://doi.org/10.23689/fidgeo-769

Romanek CS, Grossman EL, Morse JW (1992) Carbon isotopic fractionation in synthetic aragonite and calcite: effects of temperature and precipitation rate. Geochim Cosmochim Acta 56(1):419-430. https://doi.org/10.1016/0016-703 7(92) $90142-6$

Rosenheim BE, Swart PK, Thorrold SR (2005b) Minor and trace elements in sclerosponge Ceratoporella nicholsoni: biogenic aragonite near the inorganic endmember? Palaeogeogr Palaeoclimatol Palaeoecol 228(1-2):109-129. https://doi.org/10.1016/j.palaeo.2005.03.055

Rosenheim BE, Swart PK, Thorrold SR, Eisenhauer A, Willenz P (2005a) Salinity change in the subtropical Atlantic: secular increase and teleconnections to the North Atlantic Oscillation. Geophys Res Lett 32(2):L02603. https://doi. org/10.1029/2004GL021499

Rosenheim BE, Swart PK, Thorrold SR, Willenz P, Berry L, Latkoczy C (2004) Highresolution $\mathrm{Sr} / \mathrm{Ca}$ records in sclerosponges calibrated to temperature in situ. Geology 32(2):145-148 https://doi.org/10.1130/G20117.1

Rosman KJR, Chisholm W, Boutron CF, Candelone JP, Görlach U (1993) Isotopic evidence for the source of lead in Greenland snows since the late 1960s. Nature 362(6418):333-335. https://doi.org/10.1038/362333a0

Rosenheim BE, Swart PK, Willenz P (2009) Calibration of sclerosponge oxygen isotope records to temperature using high-resolution $\delta^{18} \mathrm{O}$ data. Geochim Cosmochim Acta 73:5308-5319. https://doi.org/10.1016/j.gca.2009.05.047

Saha N, Rodriguez-Ramirez A, Nguyen AD, Clarka TR, Zhao J, Webb GE (2018) Seasonal to decadal scale influence of environmental drivers on $\mathrm{Ba} / \mathrm{Ca}$ and Y/Ca in coral aragonite from the southern Great Barrier Reef. Sci Total Environ 639:1099-1109 https://doi.org/10.1016/j.scitotenv.2018.05.156

Shen GT, Boyle EA (1987) Lead in corals: reconstruction of historical industrial fluxes to the surface ocean. Earth Planet Sci Lett 82(3-4):289-304. https://doi. org/10.1016/0012-821X(87)90203-2

Stuiver M, Polach HA (1977) Discussion reporting of ${ }^{14} \mathrm{C}$ data. Radiocarbon 19(3): 355-363. https://doi.org/10.1017/S0033822200003672

Suzuki A, Kawamura N, Itaki T, Katayama H, Murakami S, Usami T, Kuroyanagi A (2009) Geochemical analyses on seawater samples collected during the GH08 cruise in the eastern offshore of Okinawa Island. In: Arak K (ed) Marine Geological and Geophysical Studies around Okinawa Islands eastern off of Okinawa Island, Preliminary Reports on Researches in the 2008 Fiscal Year, GSJ Interim Rep 46. Geol Surv Jpn, Natl Inst Adv Ind Sci and Technol, Tsukuba, pp 86-92

Swart PK, Greer L, Rosenheim BE, Moses CS, Waite AJ, Winter A, Dodge RE, Helmle $\mathrm{K}$ (2010) The ${ }^{13} \mathrm{C}$ Suess effect in scleractinian corals mirror changes in the anthropogenic $\mathrm{CO}_{2}$ inventory of the surface oceans. Geophys Res Lett 37(5):L05604. https://doi.org/10.1029/2009GL041397 
Swart PK, Thorrold S, Rosenheim B, Eisenhauer A, Harrison CGA, Grammer M, Latkoczy C (2002) Intra-annual variation in the stable oxygen and carbon and trace element composition of sclerosponges. Paleoceanography 17(3):104517-12. https://doi.org/10.1029/2000PA000622

Takahashi T, Sutherland SC, Wanninkhof R, Sweeney C, Feely RA, Chipman DW, Hales B, Friederich G, Chavez F, Sabine C, Watson A, Bakker DCE, Schuster U, Metzl N, Yoshikawa-Inoue H, Ishii M, Midorikawa T, Nojiri Y, Körtzinger A, Steinhoff T, Hoppema M, Olafsson J, Arnarson TS, Tilbrook B, Johannessen T, Olsen A, Bellerby R, Wong CS, Delille B, Bates NR, de Baar HJW (2009) Climatological mean and decadal change in surface ocean $\mathrm{pCO}_{2}$, and net Sea-air $\mathrm{CO}_{2}$ flux over the global oceans. Deep-Sea Res II 56(8-10):554-577. https://doi.org/10.1016/j.dsr2.2008.12.009

Takayanagi H, Asami R, Abe O, Miyajima T, Kitagawa H, Iryu Y (2012) Carbon- and oxygen-isotope compositions of a deep-water modern brachiopod Campagea japonica collected off Aguni-jima, Central Ryukyu Islands, southwestern Japan. Geochem J 46(2):77-87. https:/doi.org/10.2343/geochemj.1.0153

Tarutani T, Clayton RN, Mayeda TK (1969) The effect of polymorphism and magnesium substitution on oxygen isotope fractionation between calcium and carbonate and water. Geochim Cosmochim Acta 33(8):987-996. https:// doi.org/10.1016/0016-7037(69)90108-2

Vacelet J (1985) Coralline sponges and the evolution of Porifera. In: Conway Morris S, George JD, Gibson R, Platt HM (eds) The origins and relationships of lower invertebrates. Clarendon Press, Oxford, pp 1-13

Waite AJ, Swart PK, Rosenheim BE, Rosenberg AD (2018) Improved calibration of the $\mathrm{Sr} / \mathrm{Ca}$-temperature relationship in the sclerosponge Ceratoporella nicholsoni: re-evaluating $\mathrm{Sr} / \mathrm{Ca}$ derived records of post-industrial era warming. Chem Geol 488:56-61 https://doi.org/10.1016/j.chemgeo.2018.03.005

Watanabe T, Kawamura T, Yamazaki A, Murayama M, Yamano H (2014) A 106 year monthly coral record reveals that the East Asian summer monsoon modulates winter PDO variability. Geophys Res Lett 41(10):3609-3614. https://doi.org/10.1002/2014GL060037

Willenz P, Hartman WD (1989) Micromorphology and ultrastructure of Caribbean sclerosponges. Mar Biol 103(3):387-401. https://doi.org/10.1007/BF00397274

Wood R (1990) Reef-building sponges. Am Sci 78:224-235

Wörheide G (1998) The reef cave dwelling ultraconservative coralline demosponge Astrosclera willeyana Lister 1900 from the Indo-Pacific. Micromorphology, ultrastructure, biocalcification, isotope record, taxonomy, biogeography, phylogeny. Facies 38(1):1-88. https:/doi.org/10.1007/BF02537358

Wörheide G, Reitner J, Gautret P (1997) Comparison of biocalcification processes in the two coralline demosponges Astrosclera willeyana Lister 1900 and "Acanthochaetetes" wellsi Hartman and Goreau 1975. In: Lessios HA, Macintyre IG (eds) Proc 8th Int Coral Reef Symp. Smithsonian Tropical Research Institute, Panama, pp 1427-1432

Wu HC, Grottoli AG (2010) Stable oxygen isotope records of corals and a sclerosponge in the Western Pacific warm pool. Coral Reefs 29(2):413-418. https://doi.org/10.1007/s00338-009-0576-7

Zhang J, Quay PD, Wilbur DO (1995) Carbon isotope fractionation during gaswater exchange and dissolution of $\mathrm{CO}_{2}$. Geochim Cosmochim Acta 59(1): 107-114. https://doi.org/10.1016/0016-7037(95)91550-D

Zheng J, Tan MG, Shibata Y, Tanaka A, Li Y, Zhang GL, Zhang YM, Shan Z (2004) Characteristics of lead isotope ratios and elemental concentrations in PM10 fraction of airborne particulate matter in Shanghai after the phase-out of leaded gasoline. Atmos Environ 38(8):1191-1200. https://doi.org/10.1016/j.a tmosenv.2003.11.004

\section{Publisher's Note}

Springer Nature remains neutral with regard to jurisdictional claims in published maps and institutional affiliations.

\section{Submit your manuscript to a SpringerOpen ${ }^{\circ}$ journal and benefit from:}

- Convenient online submission

- Rigorous peer review

- Open access: articles freely available online

High visibility within the field

- Retaining the copyright to your article

Submit your next manuscript at $\boldsymbol{\nabla}$ springeropen.com 